\title{
A mulher moderna vai a Hollywood: a representação de feminilidade no editorial de moda da Rhodia Têxtil em parceria com a revista Claudia (abril de 1967)
}

The modern woman goes to Hollywood: femininity representation in the fashion editorial of Rhodia Têxtil in partnership with Claudia magazine (April 1967)

hitps://doi.org/10.1590/1982-02672021v29e14

\author{
GABRIELA SOARES CABRAL' \\ https: / / orcid.org/0000-0002-3410-3839 \\ Universidade Federal de Juiz de Fora / Juiz de Fora, MG, Brasil
}

RESUMO: A revista Claudia, lançada pela Editora Abril em 1961, se desenvolveu interligada aos aspectos da modernização da sociedade brasileira e com a constituição da sociedade de consumo. Trazendo a proposta de ser a revista "amiga da mulher moderna", o periódico mesclou em suas páginas modelos tradicionais de feminilidade e as mudanças dos novos tempos. Este artigo visa analisar a representação imagética da "mulher moderna" no editorial de moda em parceria com a Rhodia têxtil publicado em abril de 1967. Ao buscar apreender como a publicação utilizou a fotografia de moda para construir a imagem da mulher pautada pelo consumo e pela modernidade durante um período em que o Brasil passava por transformações de ordem política, econômica, social e cultural, este trabalho visa contribuir com os estudos de cultura visual e de gênero no país.

PALAVRAS-CHAVE: Claudia. Cultura visual. Fotografia. Mulher moderna.

1. Doutoranda em Arte, Moda: História e Cultura pelo Programa de Pós-graduação em Artes, Cultura e Linguagens na Universidade Federal de Juiz de Fora (UFJF). Graduada em Comunicação Social - Jornalismo pela UFJF, pós-graduada em Moda, Cultura de Moda e Arte e mestra em Arte, Moda: História e Cultura pelo Programa de Pós-graduação em Artes, Cultura e Linguagens pela mesma instituição. E-mail: <gabriela.soarescabral@ gmail.com> 
ABSTRACT: Claudia magazine, launched by Editora Abril in 1961, was developed in connection with aspects of modernization of Brazilian society and its consumer society constitution. Bringing the proposal to be the magazine "friend of the modern woman", the periodical merged in its pages the traditional models of femininity and the changes brought by new times. Therefore, this article aims to analyze the image of the "modern woman" in the fashion editorial in partnership with Rhodia Têxtil published in April 1967. Seeking to understand how the publication used fashion photography to build an image of this woman based on consumption and modernity during a period in which Brazil underwent through political, economic, social and cultural transformations, this work aims to contribute to the studies of visual culture and gender in the country.

KEYWORDS: Claudia. Visual culture. Photography. Modern woman. 
Século XX foi marcado por transformações de ordem econômicas, políticas, culturais e sociais que resultaram em mudanças na história da mulher no que se refere a suas representações e a seu papel de gênero. Em razão dessas modificações que levaram a uma ampliação dos direitos e oportunidades do sexo feminino, ao lado de um maior controle de suas identidades, este período foi denominado de "o século das mulheres" por George Duby e Michelle Perrot. ${ }^{2}$

Com base nestas transformações, Carla Bassanezi Pinsky ${ }^{3}$ divide a feminilidade no século XX em dois momentos: um em que esses modelos se consolidam, do início do século XX à década de 1960; e outro de maior fluidez, referente a meados dos anos 1960 até os dias atuais. Este primeiro momento, denominado pela autora "era dos modelos rígidos", foi o período em que os padrões de feminilidade se consolidaram e definiram-se condutas cujas normas demarcavam que tipo de mulher seria digna de respeito social, estabelecendo um papel de feminilidade ligado à dona de casa, esposa e mãe, segundo uma visão pretensamente "natural" da mulher. A partir dos anos 1960, a imagem da mulher passaria por mudanças em decorrência de fenômenos políticos, econômicos e sociais que acarretariam na maior fluidez destes modelos, sendo por isso chamado de "era dos modelos flexíveis". ${ }^{4}$

Estas transformações podem ser vistas através das páginas das revistas femininas. Por trás de matérias sobre namoros, casamento, maternidade, juventude, sexualidade e trabalho, os periódicos revelam mudanças e permanências nos costumes, nas relações familiares, nas normas sociais e nas regras de comportamento. ${ }^{5}$

\footnotetext{
À primeira vista, receitas de culinária, conselhos de beleza, contos de amor e outros assuntos - comuns às revistas, seções e suplementos femininos do mundo inteiro - são neutros. Porém se sairmos da superfície, veremos que a imprensa feminina é mais 'ideologizada' que a imprensa dedicada ao público geral. ${ }^{\circ}$
}

Além disso, Carla Bassanezi Pinsky ${ }^{7}$ ressalta que a imprensa feminina ajuda a formar gostos, opiniões, padrões de consumo e modelos de conduta. Através de linguagem coloquial e íntima, a revista aconselha e indica condutas para sua leitora, cumprindo, desta maneira, funções pedagógicas. ${ }^{8}$

Porém, é preciso destacar que revistas são produtos comerciais e, portanto, são feitas para serem vendidas, atrair anunciantes e gerar lucro a seus produtores, logo precisam fidelizar um bom número de leitores. Por isso, a
3. Cf. Pinsky (2014).

4. Ibid.

5. Buitoni (2009); Pinsky (2014).

6. Buitoni (2009, p. 21).

7. Cf. Pinsky (2014).

8. Luca (2012). 
9. Pinsky (2014).

10. Rhodia é o nome adotado pela filial brasileira da empresa francesa Rhône-Poulenc, instalada no Brasil desde 1919. Em 1955 a firma obtém a patente para a fabricação de fios sintéticos no país (Bonadio, 2014).

11. Ao lado de outro nomes, ambas faziam parte da "Seleção Rhodia Moda", grupo de modelos que apareciam nos editoriais produzidos para as revistas Jóia e Claudia com nomes creditados, porém, a maior parte era composta por apelidos criados por Livio Rangan com o intuito de "melhorar o som" dos nomes (BONADIO, 2014).

12. Rainho (2014).

13. Ibid.

14. Mauad (2005).

15. Cf. Berger (1972). imprensa feminina busca refletir um consenso social - retratar em suas páginas ideias dominantes sobre os papéis masculinos e femininos. Assim, é preciso relativizar a relação entre estas publicações e seu tempo, na medida em que as revistas sofrem interferência do contexto social, funcionando como termômetro dos costumes de uma determinada época, em que cada transformação social ou cultural acaba sendo adotada pela sociedade. Portanto, a imprensa feminina não é um espelho fiel da realidade, e sim uma visão, uma interpretação. ${ }^{9}$

Logo, o objetivo deste artigo é compreender como a mulher era representada imageticamente na imprensa feminina durante este período de transição da "era dos modelos rígidos" para a "era dos modelos flexíveis", que se desenrola durante a década de 1960. Para isso, adotamos como objeto de estudo a revista Claudia, lançada pela Editora Abril em 1961. O periódico, que se desenvolveu imbricado com aspectos da modernização da sociedade brasileira e com a constituição da sociedade de consumo, trazia a proposta de ser a revista "amiga da mulher moderna". Apesar de apresentar em suas páginas elementos destas transformações, a revista ainda trazia modelos tradicionais de feminilidade.

Assim, para compreender esta representação de feminilidade, este trabalho abordará o editorial de moda da revista realizado em parceria com a empresa Rhodia Têxtillo publicado em abril de 1967. Fotografado por Lew Parrella (19272014), as imagens trazem as modelos Mila e Betina" ao lado de atores consolidados pelo cinema de Hollywood e seus estúdios. A justificativa para a escolha deste editorial está no fato de que, apesar da edição datar da segunda metade da década de 1960, quando supostamente as transformações já estariam estabelecidas, apresenta muitos elementos associados à representação feminina pautada pela domesticidade e subordinação. Além disso, a moda passa por uma mudança significativa em 1966 que reflete essas alterações de comportamento e que influenciam as representações femininas na mídia. ${ }^{12}$

As imagens são privilegiadas nesta análise, pois, a partir da fotografia de moda, é possível pensar as sociedades, suas rupturas e permanências. ${ }^{13}$ Embora já não se utilize a concepção de que o registro fotográfico é a realidade em sua forma pura e simples, é preciso lembrar que sua representação apresenta uma série de códigos calcados em contextos culturais e históricos. ${ }^{14}$ Assim, John Berger ${ }^{15}$ ressalta que toda imagem corporifica um modo de ver, elucidando que a fotografia herdou a tradição, os costumes e convenções da representação da mulher apreendida no decorrer da história do Ocidente. Para o mesmo autor, a mulher apresenta uma aparência social diferente do homem, uma vez que a presença masculina pertence ao campo da ação, ou seja, sugere o que o homem pode fazer 
por nós ou para nós, enquanto a presença feminina se manifesta na aparência, através de gestos, roupas, voz e ambientes que frequenta:

Os homens agem e as mulheres aparecem. Os homens olham para as mulheres. As mulheres veem-se a serem vistas. Isto determina não só a maioria das relações entre homens e mulheres como também as relações das mulheres consigo próprias. $\bigcirc$ vigilante da mulher dentro de si própria é masculino: a vigiada, feminina. Assim, a mulher transforma-se a si própria em objeto - e muito especialmente num objeto visual: uma visão. ${ }^{16}$

Como aporte teórico, nos debruçamos sobre trabalhos como Liberdade é uma calça velha azul e desbotada, de Anna Cristina Camargo Moraes Figueiredo, ${ }^{17}$ que nos ajuda a compreender melhor as transformações que vinham se delineando no país; Moda e revolução nos anos 1960, de Maria do Carmo Rainho, ${ }^{18}$ e Moda e publicidade no Brasil nos anos 1960, de Maria Claudia Bonadio, ${ }^{19}$ de modo a apreender as mudanças dos costumes pelo país durante a referida década e seus impactos na moda, na publicidade e na fotografia.

Para a análise das imagens, seguiremos a proposta de Ana Maria Mauad. ${ }^{20}$ Em Na mira do olhar: um exercício de análise da fotografia nas revistas ilustradas cariocas, na primeira metade do século XX, a autora propõe uma metodologia baseada na análise interdisciplinar da imagem. Ao considerar a fotografia como resultado de um trabalho social de produção de sentido, a autora sugere uma abordagem seriada, isto é, para ser trabalhada de forma crítica a imagem não deve ser limitada a um simples exemplar, pois é através do cotejo de exemplares que podemos ver aquilo que se repete ou que diverge. Para isso, usaremos também a metodologia de Maria do Carmo Rainho, ${ }^{21}$ na qual as imagens são separadas em blocos para que se possa ter uma visão das exceções e permanências.

Ao debruçarmos sobre este método, é preciso lembrar que as imagens nunca estão privadas das palavras - legendas, títulos, enunciados ${ }^{22}$ - e que neste sentido o texto condiciona o olhar. ${ }^{23}$ " $\bigcirc$ texto constitui uma mensagem parasita, destinada a conotar a imagem, isto é, a lhe 'insuflar' um ou vários significados segundos", 24 porém, nesta pesquisa a fotografia consiste em mensagem e não em mera ilustração do texto verbal.
16. Ibid. (p. 51).

17. Cf. Figueiredo (1998).

18. Cf. Rainho (2014).

19. Cf. Bonadio (2014).

20. Cf. Mauad (2009).

21. Cf. Rainho (2014).

22. Ibid.

23. Berger (1972).

24. Barthes (1990, p. 19). 
26. Pinsky (2014).

27. Cf. Costa (2009).

28. Figueiredo (1998, p. 72).

29. Mello; Novaes (1998, p. 631).

30. Figueiredo (1998).

31. Ibid. (p. 31).
CLAUDIA E AS TRANSFORMAÇÕES DA SOCIEDADE BRASILEIRA NA DÉCADA DE 1960

Após a Segunda Guerra Mundial (1939-1945) o mundo seria marcado por um extraordinário crescimento econômico e transformações sociais, período que Eric Hobsbawm ${ }^{25}$ chamou de "Era de Ouro" (1945-1973). Embora não tenha sido hegemônico, o desenvolvimento nos meios de comunicação e de transporte permitiram que o mundo se tornasse uma unidade, possibilitando que os grandes centros industriais instalassem em outros países seu foco de produção. Isto propiciaria um clima de otimismo no Brasil, que ingressou dos anos 1946 a 1964 na fase de desenvolvimento acelerado, em que a industrialização e a urbanização avançaram de forma inédita. A partir da intensificação da influência do capital estrangeiro ocorrida a partir do governo Juscelino Kubitschek (1956-1961), que impulsionou a indústria no país, os padrões de consumo alteraram-se. Através da democratização do acesso aos produtos industrializados propiciado pelo crescimento das camadas médias da população, grupos mais amplos da sociedade foram elevados ao status de consumidores. ${ }^{26}$

Os processos de mudança de comportamentos e costumes iniciados em 1960, para Maria Paula Costa, ${ }^{27}$ foram influenciados pela crescente urbanização e pela ideia de modernização que ajudaram a criar uma indústria cultural no país. De acordo, com Ana Cristina Figueiredo, o crescimento urbano e industrial ocorrido em algumas regiões do Brasil colaborou para a gestação de uma "classe média" urbana, representada por funcionários públicos, empresários e comerciantes, que ao longo do tempo se tornou "afluente, razoavelmente bem informada, com dinheiro no bolso e vontade de gastar". ${ }^{28}$ Esta nova camada tinha como característica estar "plenamente integrada nos padrões de consumo moderno de massas, de alimentação, de vestuário, de higiene pessoal e beleza, de higiene da casa". ${ }^{29}$

Assim, o sucesso e o consumo estavam relacionados: a publicidade e os meios de comunicação esboçavam uma sociedade aberta e plena de oportunidades que incitava a ascensão social e pessoal. Mas esta projeção não seria alcançada pelas qualificações e pelo desempenho profissional, e sim em virtude do que a mulher aparentava ser pelos bens que adquiria e pela maneira como se portava. ${ }^{30}$ Isto era evidente nas publicidades da época:

Da simples lâmina de barbear ao mais requintado automóvel, não havia nos anos 50 e 60 bem de consumo que não se pretendesse "moderno", "novo" ou "inédito". Esses bens eram oferecidos a homens e mulheres igualmente "modernos, afinados com os "novos tempos" e vivendo em perfeita consonância com o "progresso". 31 
Esta busca pela modernidade através do consumo foi corroborada pelos meios de comunicação de massa que funcionavam como vitrines para "exposição de produtos e de novos valores sociais para uma sociedade que estava sob a expectativa criada pelo desenvolvimento". ${ }^{32}$ Deste modo, os indivíduos buscavam se firmar cada vez mais através do consumo, ou seja, era através da "manipulação de signos que se associavam aos objetos de consumo que o indivíduo forjava uma imagem de si mesmo, que definia sua personalidade, usando como referência o modelo adotado pelo grupo ao qual ele pretendia filiado". ${ }^{33}$

É nesta conjuntura política, econômica e cultural que a revista Claudia chega às bancas de todo o Brasil. Criada pela Editora Abril em outubro de 1961 e em circulação até os dias atuais, a publicação foi a responsável por consolidar a imprensa feminina no país. Já havia um mercado consumidor para publicações voltadas para o público feminino quando a revista foi criada, porém, Claudia foi a publicação dirigida à mulher dona de casa da emergente classe média urbana. ${ }^{34}$ Com o objetivo editorial de ser "revista amiga" e facilitar a vida da leitora, o periódico estabeleceu como público-alvo a mulher casada e mãe que dedicava seu tempo "aos cuidados da família e com poder para decidir ou pelo menos influir na escolha e no consumo de vasta gama de produtos - alimentos, produtos de higiene e beleza, roupas, remédios, móveis, utensílios e eletrodomésticos". ${ }^{35}$

Claudia foi a publicação que introduziu no país o estilo "magazine moderno". ${ }^{36} \bigcirc$ veículo representou a transformações das "fórmulas editoriais de revista feminina da primeira metade do século XX nos quais a mulher era apenas pensada como esposa e mãe, para o modelo contemporâneo, onde encontram lugar também seus problemas pessoais e seus direitos como mulher" ${ }^{37}$

Com tiragem inicial de 164 mil exemplares - número significativo para a época - Claudia foi o abrasileiramento de uma fórmula de periódicos femininos mensais que já circulavam há algum tempo na Europa e nos Estados Unidos. ${ }^{38}$ Desde o início a revista se apresentou como uma publicação moderna, diferente e fruto dos novos tempos, como demonstra o editorial enviado aos anunciantes em julho de 1961 :

Por que Claudia? $\bigcirc$ Brasil está mudando rapidamente. A explosiva evolução da classe média torna necessária uma revista para orientar, informar e apoiar o crescente número de donas de casa que querem (e devem) adaptar-se ao ritmo da vida moderna. Claudia será dirigida a estas mulheres e será dedicada a estas mulheres e será dedicada a encontrar soluções para seus novos problemas. Claudia não esquecerá, porém, que a mulher tem mais interesses em polidores do que em políica, mais em cozinha do que em contrabando, mais em seu próprio corpo do que em outros planetas... Claudia, enfim, entenderá que o eixo da mulher é seu lar. ${ }^{39}$
32. Costa (2009, p. 23).

33. Figueiredo (1998, p. 99).

34. Ibid.

35. Luca (2012, p. 454).

36. Pinsky (2014).

37. Mira (2008, p. 59).

38. Ibid.

39. Pinsky (2014, p. 40). 
40. Cf. Buitoni (2009).

41. Cf. Rainho (2014).

42. Pinsky (2014, p. 44)

43. Luca (2012, p. 457).

44. Mira (2008, p. 11).

45. Cf. Costa (2009).

46. Termo utilizado para se referir aos anúncios da Rhodia na revista Claudia que muitas vezes passavam despercebidos como conteúdo do próprio periódico (BONADIO, 2014).

47. Cf. Bonadio (2014).
Segundo Dulcília Buitoni, ${ }^{40}$ na imprensa feminina até os anos 1970 a mulher estava ligada a papéis sociais básicos: dona de casa, esposa e mãe. Porém, Maria do Carmo Rainho ${ }^{41}$, ao estudar as transformações da moda nos anos 1960, começa a notar um período de transição no tratamento das questões femininas no periódico Correio da Manhã (190 1-1974), uma vez que seções como moda, beleza, receitas e conselhos sobre maternidade e relação conjugal começavam a dividir espaço com textos sobre sexualidade, crises no casamento e uso da pílula anticoncepcional.

O mesmo pode ser visto em Claudia. Apesar da publicação trazer a proposta de ser "amiga da mulher moderna", ela traz majoritariamente o modelo tradicional de feminilidade. Deste modo, "convivem na mesma revista [...] a preocupação de moldar 'boas esposas' ao lado da concepção de 'mulher moderna' que não vive única e exclusivamente para o marido e para os filhos e procura ter participação ativa no mundo fora do âmbito doméstico". ${ }^{42}$ Deste modo, "novos e velhos valores mesclam-se num balé sutil que atava-se ao passado, sem, contudo, ignorar as mudanças em curso", ${ }^{43}$ pois, como salienta Maria Celeste Mira, "para sobreviver, uma revista tem de acompanhar rapidamente as mudanças de seu público". ${ }^{44}$

A "mulher moderna" leitora de Claudia encontrou, então, nas páginas da revista uma forma de se incluir nessa nova fase de modernização da sociedade. Assim, a publicação procurou influenciar diretamente nos comportamentos e costumes da classe média em franca expansão que buscava orientações para se adequar aos novos tempos, por causa da urbanização e industrialização vivenciadas pelo Brasil. ${ }^{45}$

\section{CLAUDIA E RHODIA TÊXTIL: "PUBLIEDITORIAIS"46 DE MODA}

Em seu livro Moda e publicidade no Brasil dos anos 1960,47 Maria Claudia Bonadio, ao traçar a história do fio sintético no Brasil e sua importância para a moda brasileira através da publicidade da empresa francesa Rhodia, destaca como a produção de nylon no país alterou o quadro geral da indústria têxtil nacional. A autora relata que em 1956, quando o produto começou a ser produzido no Brasil, sua utilização ainda era restrita a poucas peças, como meias finas, malharias, roupas profissionais, trajes impermeáveis, correias de transmissão e filtros industriais. Ele só começaria a ser empregado na composição de roupas de moda somente nos anos 1960.

No mesmo período, o mercado de roupas prontas - prêt-à-porter - começa a emergir e encontra no Brasil condições favoráveis ao seu desenvolvimento, como 
a popularização das fibras sintéticas, entre outros fatores que propiciam a ampliação e a diversificação da produção de produtos de vestuário. Segundo Maria Claudia Bonadio, ${ }^{48}$ a Rhodia colaborou para a expansão deste mercado através de sua política publicitária. Implementada por Livio Rangan (1933-1984), a publicidade da empresa visava atingir a consumidora final, portanto, era preciso mostrar mais que fios e tecidos, ou seja, mais que mostrar as peças de roupas feitas com esses materiais. Deste modo, a Rhodia buscava não apenas vender seus fios, mas também a ideia de uma "moda nacional" de qualidade internacional criada pela empresa.

Apesar da ampliação da indústria têxtil nacional e de sua variedade de produtos, as classes alta e média do país continuavam preferindo importar tecidos, destacando, assim, a necessidade de sofisticar os produtos e investir em publicidade para valorizá-los diante do público consumidor. ${ }^{49}$

Assim, as revistas constituíram-se como veículos centrais de divulgação da publicidade da Rhodia durante os anos 1960. Inicialmente as publicidades da Rhodia eram condensadas em revistas de variedade como O Cruzeiro (19281975) e Manchete (1952-2000), porém, ao longo da década os anúncios da empresa se concentrariam nas publicações especializadas no público feminino. Conforme ressalta Dulcília Buitoni, 50 neste período há o estreitamento entre publicidade e revistas femininas, uma vez que estes periódicos têm como principal objetivo o consumo, trazendo, portanto, cada vez mais anúncios. "Tudo o que vai dentro de uma revista ou está ligado diretamente a um produto (moda e maquiagem por exemplo) ou serve de atrativo para que a revista seja comprada e com isso divulgue a publicidade nela contida. ${ }^{51}$ Deste modo, tornara-se cada vez mais difícil distinguir conteúdo jornalístico e publicitário. ${ }^{52}$

De acordo com Maria Claudia Bonadio, ${ }^{53}$ o primeiro editorial de moda da Rhodia produzido por Livio Rangan teria sido publicado na edição de maio de 1960 da revista Manequim (1959-1, periódico cujo principal objetivo era apresentar moldes de modelos a serem confeccionados em casa ou por costureiras. Conforme a autora, a produção de editoriais de moda da Rhodia para a publicação se encerrou em 1961, provavelmente em consequência do lançamento de Claudia, pois a partir deste ano o anunciante passou a publicar seus editoriais na nova publicação. Ao contrário de Manequim, Claudia nunca publicou moldes, mas, sim, fotografias de roupas prontas de marcas nacionais, colaborando, assim, para esse mercado até então incipiente no Brasil.

A relação entre Claudia e Rhodia se estreitou ao ponto de profissionais que trabalharam para a revista ao longo dos anos 1960 citarem o anunciante como parte importante da história da moda e da história da revista. $\bigcirc$ depoimento do jornalista e escritor Ignácio de Loyola Brandão reforça esta relação:
48. Ibid.

49. Prado; Braga (2019).

50. Cf. Buitoni (2009).

51. Buitoni (2009, p. 104)

52. Luca (2012).

53. Cf. Bonadio (2014) 
54. Apud Bonadio (2014, p. 137).

55. Ibid. (p. 137).

56. Bonadio (2014).

57. Cf. Campbell (2011).
Claudia ajudou na formação de uma moda nacional, porque a indústria de moda nacional não existia. A existência da revista possibilitou um espaço de divulgação para essa nova indústria chegar às mulheres. [...] Você pode ver que a evolução da Claudia e a evolução da Rhodia estão muito ligadas, caminharam juntas, trabalharam juntas. A Claudia era o veículo onde a Rhodia colocava seus produtos. ${ }^{54}$

A participação da publicidade da Rhodia em Claudia não se restringiv aos espaços publicitários, uma vez que as capas da revista muitas vezes traziam o material elaborado pela anunciante. "No começo, as capas de Claudia eram reproduções dos desenhos estampados na edição argentina da revista. Sua primeira capa fotográfica, em maio de 1963, resultou de uma viagem à França realizada em parceria com a Rhodia". 55

\begin{tabular}{|l|l|}
\hline Edição & Local \\
\hline Abril de 1966 & Nova York \\
\hline Abril de 1967 & Hollywood \\
\hline Outubro de 1967 & Côte d'Azur \\
\hline Maio de 1968 & Moscou \\
\hline Outubro de 1968 & Espanha \\
\hline Maio de 1969 & Suécia \\
\hline Outubro de 1969 & Londres \\
\hline
\end{tabular}

Tabela 1 - Parcerias Rhodia e Claudia entre os anos 1966 e 1969.

Os editoriais da Rhodia eram publicados na Claudia cerca de uma a duas vezes no ano, e em sua grande maioria era parte de edições temáticas realizadas em outros países. ${ }^{56}$ Esta prática de realizar "editoriais turísticos" se tornou comum nas revistas de moda a partir da passagem de Diana Vreeland (1903-1989) na revista Harper's Bazaar entre os anos 1936 e 1961 nos quais trabalhou como editora de moda da publicação. $\bigcirc$ documentário $\bigcirc$ olhar tem que viajar (Diana Vreeland: The eye has to travel, Lisa Immordino Vreeland, 2011 ) elucida que para Vreeland seu papel como editora era dar às pessoas algo que não tivessem em casa, algo para que pudessem viajar em suas mentes.

Contudo, é importante considerar o uso de imagens de viagem ao exterior em um contexto no qual ainda era pouco expressivo o número de brasileiros que podiam desfrutar desta experiência. Isto pode ser explicado pelo "prazer imaginativo" delineado por Colin Campbell, ${ }^{57}$ um conceito que expressa a sensação de desfrutar essas imagens da mesma forma que se desfruta de um 
romance ou um filme. Para o autor, a atividade central do consumo está neste prazer imaginativo, e não no ato da seleção, compra ou uso do produto em si.

No Brasil dos anos 1960, a "grande classe média brasileira" que vinha se estabelecendo era um grande grupo com "certa disponibilidade econômica" e em busca de algo mais que bens de primeira necessidade, predisposto a consumir um vestuário "na moda" e original. Daí a necessidade de um tipo de publicidade que vendesse não apenas a utilidade das roupas confeccionadas em tecidos feitos com fios sintéticos (Tergal, Rhodianyl, Rhodalba, Rhodimper etc.), mas também a série de dispositivos e signos distintivos associados a ela. ${ }^{58}$

No que se refere a esses materiais produzidos no exterior, Thomaz Souto Corrêa (1940), diretor da revista no período, afirmou em entrevista a Maria Claudia Bonadio 59 que as equipes da Rhodia e Claudia viajavam juntas a países estrangeiros para realizar edições temáticas sobre a moda e a cultura desses países, porém, cada um realizava seu trabalho. $\bigcirc$ diretor enfatizou que a participação do anunciante na publicação era limitada ao espaço publicitário, entretanto, a observação das imagens demonstrou que as produções da Rhodia acabavam se misturando aos editoriais produzidos pelo periódico, uma vez que em muitas ocasiões os materiais da revista e do anunciante eram realizados pelos mesmos profissionais, devido à incipiência do campo profissional da moda no Brasil. 60 Portanto, ao valorizar a moda nacional, Claudia criou condições para a profissionalização da área no país, abrindo espaço para a emergência de fotógrafos, modelos e produtores de moda. ${ }^{61}$

Deste modo, a valorização da moda pela publicação a tornou um espaço privilegiado para os anúncios da Rhodia, que provavelmente era a maior anunciante da revista nesse período, 62 uma vez que "Claudia funcionava, também, como guia de compras, orientando as leitoras sobre as novidades que o mercado colocava à sua disposição". ${ }^{63}$

\section{À MODA DE HOLLYWOOD}

Publicada em abril de 1967, a edição Claudia apresenta Hollywood se diferencia das demais a partir da capa, que apresenta uma fotografia de Lew Parrella na qual as modelos Mila e Betina aparecem juntamente com o cineasta Alfred Hitchcock (1 899-1980), diretor consagrado e de sucesso, que àquela altura já havia
58. Bonadio (2014, p. 123).

59. Ibid.

60. Ibid.

61. Mira (2008).

62. Ibid.

63. Prado; Braga (2019, p. 164). 
64. Cf. Bonadio (2014).

Figura 1 - Capa das edições fevereiro de 1962, agosto de 1965, abril de 1966 e abril de 1967, respectivamente. Fonte: Claudia. Acervo Biblioteca Nacional Rio de Janeiro. lançado grande parte dos filmes que o aclamariam, como Festim diabólico (1958), Janela indiscreta (1954), Um corpo que cai (1958) e Psicose (1960). As primeiras capas de Claudia traziam ilustrações do rosto de mulheres em close-up, mas, quando passaram a trazer fotografias, esta forma de representação não se alterou, e as capas continuaram a apresentar o rosto de mulheres em enquadramento semelhante. As edições temáticas de países estrangeiros começaram a mostrar duas modelos na capa, porém a de Hollywood (Figura 1) foi a primeira a exibir na capa um homem além das modelos, o que nos sugere que, ao ostentar uma personalidade internacional na capa, a revista estaria demonstrando ao público o seu status e importância. De acordo com Maria Claudia Bonadio, ${ }^{64}$ o uso de personalidades ou simbologias do chamado "universo do privilégio" são uma forma de consagração para as marcas.

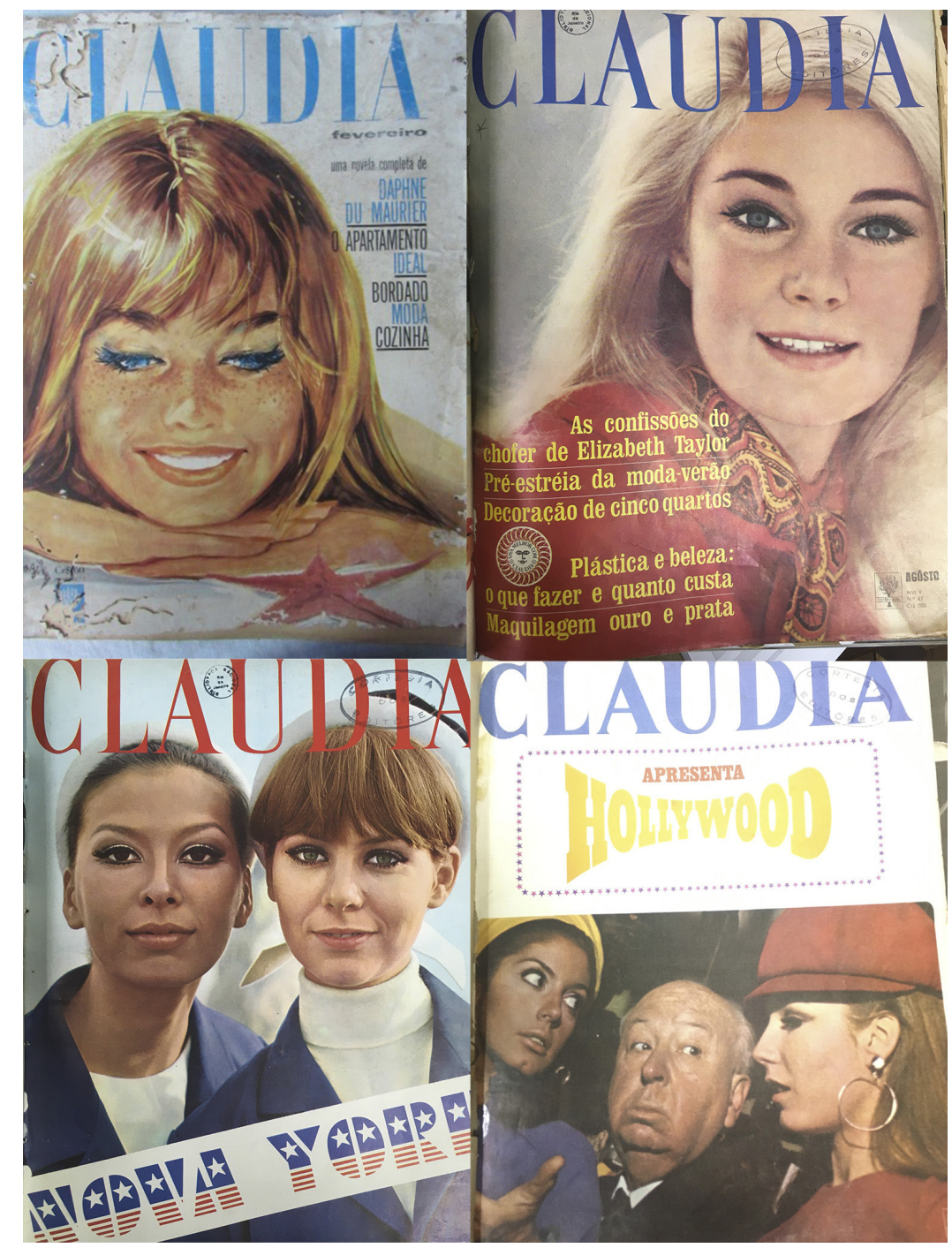


Além disso, as modelos que estampam a capa não aparecem sorrindo, como era habitual, mas apresentam semblantes desconfiados e surpresos. $\bigcirc$ diretor também não sorri e aparece com a expressão com que é comumente retratado em fotografias.

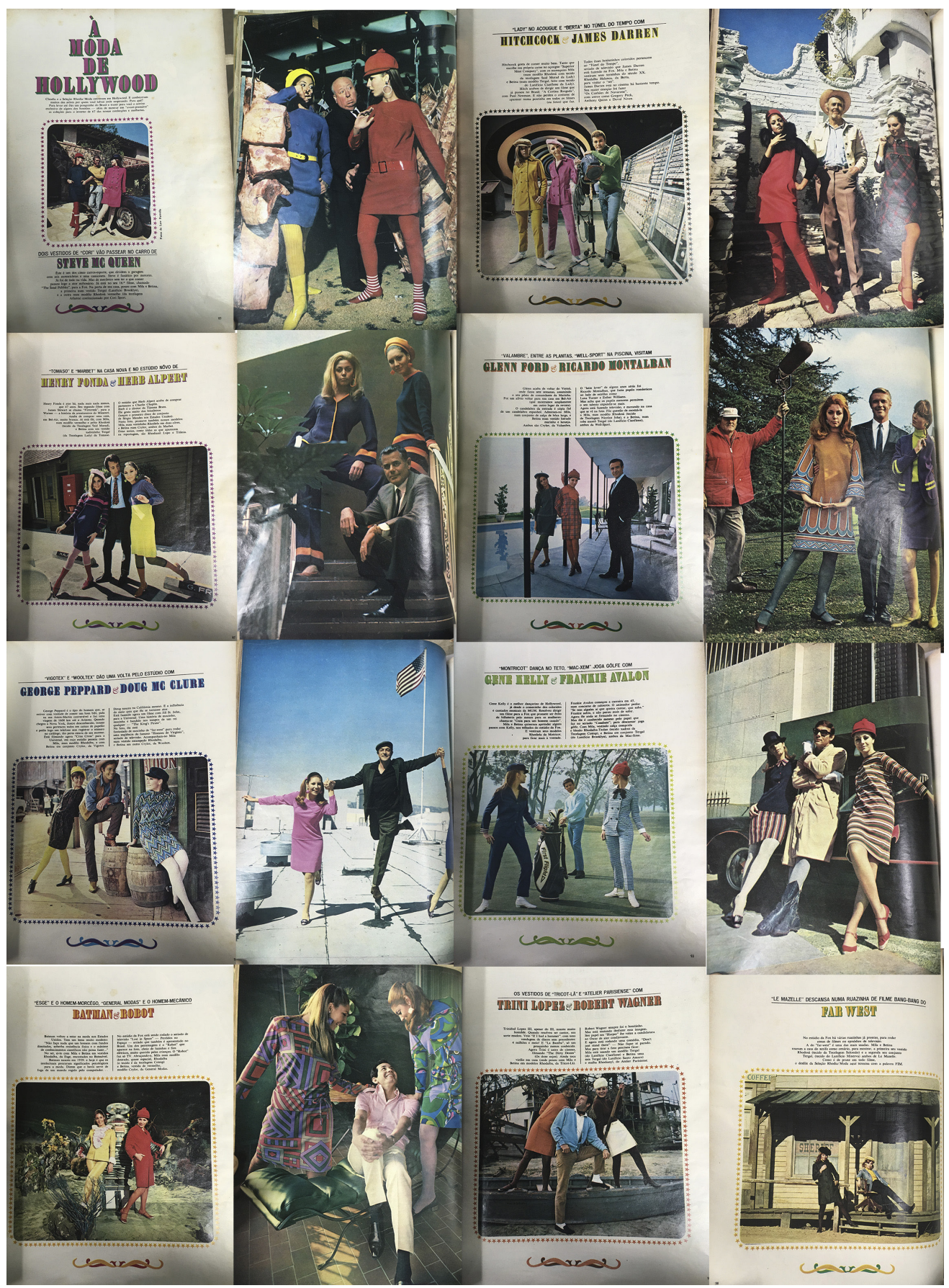

Figura 2 - Editorial "À moda de Hollywood", revista Claudia, n. 67 abril de 1967, p. 8398. Foto: Lew Parrella. Fonte: Claudia. Acervo Biblioteca Nacional - Rio de Janeiro. 
65. Claudia (1967, p. 83).

66. Bonadio (2014, p. 122).

67. Mello; Novaes (1998, p. 604).

68. Ibid.

69. Cf. Cicco (1979).

70. Mello; Novaes (1998, p. 605).
Outras personalidades hollywoodianas também aparecem dentro da série analisada. Denominado "À moda de Hollywood" (Figura 2), o editorial contém dezesseis páginas que intercalam uma foto centralizada acompanhada de textos com fotos de página inteira, e não fica explícito se se trata de um anúncio da Rhodia. Apenas no texto de introdução a empresa é mencionada:

Claudia e Seleção Rhodia/Moda estiveram em Hollywood. E conheceram muitos dos atores por quem você talvez ande suspirando. Para quê? Para levar até eles um pouquinho do Brasil e trazer para você o sorriso de alguns dos bonitões - além de mostrar em "avant-première" as coleções para o inverno de 67 das nossas confecções e malharias. ${ }^{65}$

O objetivo da revista e da empresa não era apenas conhecer Hollywood e seus galãs, mas também os apresentar ao Brasil. Conforme Maria Claudia Bonadio destaca, as campanhas da Rhodia se alinham com os ideais desenvolvimentistas do Estado autoritário entre os anos de 1964 e 1972, que visavam incentivar a participação econômica do país no mercado externo. Nesse sentido, elas eram "um instrumento direto de propaganda para o Brasil no exterior, evidenciando seu amadurecimento industrial e artístico", ${ }^{66}$ porém a empresa têxtil apenas transmitia a ideia de que o país estava sendo mostrado, já que na prática isso não acontecia.

Segundo João Manuel Cardoso de Mello e Fernando A. Novais, o progresso no país, seja ele individual ou nacional, era incorporado de maneira mecânica, através do "mimetismo, pelos 'inferiores', dos padrões de consumo e estilos de vida dos 'superiores'". ${ }^{67}$ Ou seja, para os autores, a principal via de transmissão do valor do progresso entre os brasileiros foi através da imitação dos padrões de consumo e dos estilos de vida predominantes nos países desenvolvidos.

Durante o século XIX, os modelos das classes abastadas do Brasil eram o inglês e francês, mas durante o século XX, após a Segunda Guerra Mundial (19391945), os Estados Unidos e o american way of life tornaram-se o novo alvo de fascínio. ${ }^{68}$ Cláudio de Cicco ${ }^{69}$ revela que isso se deu principalmente devido à consolidação do cinema hollywoodiano no contexto do pós-guerra. Através de suas produções cinematográficas, Hollywood introjetou na sociedade brasileira valores capitalistas de um estilo de vida calcado no consumo.

Não é por acaso que talvez o brinquedo preferido dos meninos vá se tornando o automóvel, o símbolo maior do americanismo. Nem que a riqueza seja muitas vezes identificada com o Cadillac, o carro mais luxuoso produzido nos Estado Unidos. Não é por coincidência, também, que os meninos passem a brincar de cow-boy com revólveres na mão, de metal ou de plástico. ${ }^{70}$ 
Esses valores podem ser observados no editorial fotografado pela equipe de Claudia e Rhodia em Hollywood. Nas imagens as modelos posam ao lado de diversas personalidades do período em locais que variam entre as casas dos artistas, estúdios de produtoras e cenários de filmes ou programas de TV. É interessante ressaltar que Mila e Betina são fotografadas apenas ao lado de homens. Em nenhuma imagem há a presença de uma celebridade do sexo feminino, e apenas em uma imagem as modelos são clicadas sozinhas. Além disso, todos os homens que figuram no editorial são consideravelmente mais velhos que as manequins, pois possuem entre 28 e 68 anos enquanto as modelos da Rhodia começavam a carreira com cerca de dezessete anos, exceto Mila, que iniciou no ramo aos catorze. ${ }^{71}$

Esta diferença de idade reforça como Claudia, apesar de já acompanhar as mudanças em voga, ainda permanecia atada a uma feminilidade voltada ao lar e ao marido cuja principal meta permanecia sendo o casamento e a felicidade conjugal. Assim, "mesmo dentro de limites (impostos tanto pela época e pelo tipo de público, quanto pela direção da revista composta por homens), Claudia comportava várias tendências com a predominância das mais convencionais". ${ }^{72}$

Até os anos 1960 há uma escassez de contato físico mais intenso entre homens e mulheres na fotografia de moda, mas, a partir da referida década, isto começa a se alterar. ${ }^{73}$ Porém, ao observarmos o editorial em questão, podemos ver que mesmo em 1967 a revista Claudia trazia em seus editoriais em parceria com a Rhodia pouquíssima interação entre os gêneros. Na maioria das imagens, sequer há contato físico, o que nos aponta que estes, assim como as locações, estão ali para compor um cenário e dar prestígio às mulheres e às roupas. Isso se dá principalmente quando as modelos são fotografadas ao lado dos astros mais velhos (Figura 3).

As manequins posam mais uma vez ao lado de Hitchcock. Na fotografia, o cineasta passa uma de suas mãos entre as manequins e olha para Betina, cujo gesto do braço remete a uma ação de desviar-se do cineasta. A modelo posa de uma forma em que parece ter sido clicada em meio a uma ação. Nesta imagem, nenhum dos presentes aparece sorrindo. No que se refere ao cenário, a legenda explica que o cineasta gosta de comer bem e por isso prefere escolher a própria carne. Contudo, se considerarmos que o diretor era conhecido por seu humor e que o gênero de seus filmes era o terror, podemos nos questionar se as modelos também não seriam uma espécie de carne nessa locação. A fala do fotógrafo do editorial, Lew Parrella, que gostava de ajudar na seleção de fotos que iam para a revista e foi responsável pela escolha destas, ajuda a confirmar esta hipótese:
71. Bonadio (2014).

72. Pinsky (2014, p. 43-44).

73. Rainho (2014) 
74. Monjabosco (2020).

Figura 3 - Modelos Mila e Betina acompanhadas dos astros Alfred Hitchcock, Henry Fonda, Glenn Ford e Ricardo Montalban, respectivamente. Claudia, n. 67, abril de 1967. Foto: Lew Parrella. Fonte: Claudia. Acervo Biblioteca Nacional - Rio de Janeiro.
Estávamos num frigorífico. Alfred, eu e as manequins. Era muito engraçado. Alfred fez piadas. Deixei a câmera dentro por um tempo e congelou o mecanismo. A moda que está nessa foto é ridícula, completamente estúpida. Não é uma foto de moda, é uma piada com Hitchcock. $\bigcirc$ humor dele ficou aparente na foto. ${ }^{74}$

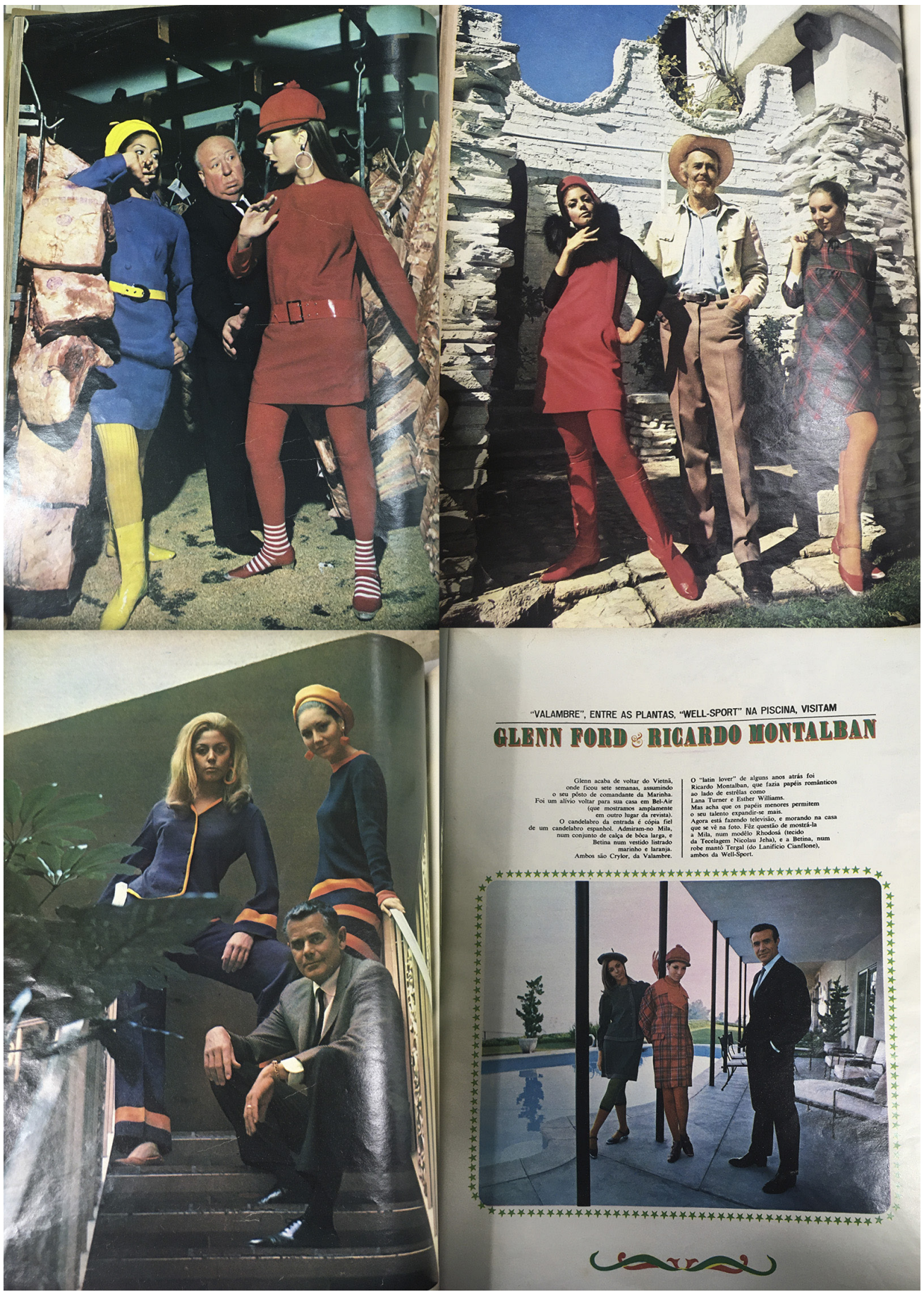


Mila e Betina também são fotografadas sem qualquer interação com Henry Fonda (1905-1982), ator que neste período já contava com 64 filmes em seu currículo e estrelou Doze homens e uma sentença (Sidney Lumet, 1957) e A conquista do Oeste (John Ford, 1962), clássico do faroeste, gênero no qual acumulou papéis. $\bigcirc$ uso do chapéu reforça a associação do astro ao cowboy de seus longas. Segundo a legenda, a locação se refere à casa recém-adquirida de Fonda em Bel-Air, o que transmite uma relação de intimidade entre ele e as manequins, além de demonstrar uma imagem de glamour.

mesmo fenômeno ocorre com Glenn Ford (1916-2006). $\bigcirc$ ator que começou sua carreira cinematográfica em 1937, teve seu nome lançado à constelação de estrelas hollywoodianas ao estrelar Gilda (Charles Vidor, 1946), grande sucesso do cinema noir, ao lado de Rita Hayworth (1918-1987). O ator, de acordo com a legenda, estava no Vietnã, ocupando seu cargo na Marinha. Ao lembrarmos que neste contexto o país em questão enfrentava uma guerra ${ }^{75} \mathrm{com}$ os Estados Unidos, é pertinente sugerir que ao ressaltar isto na legenda, Claudia e Rhodia estavam reforçando o patriotismo do ator. $\bigcirc$ texto também nos informa que a fotografia foi tirada na casa do astro - que seria mostrada com detalhes no interior da revista. Era comum que revistas especializadas em cinema deste período trouxessem em suas páginas a casa dos astros, o que, como elucida Margarida Maria Adamatti, ${ }^{76}$ era um modo de incitar indiretamente o consumo. Assim, enquanto Ford aparece sentado em uma escada, Mila e Betina posam em pé atrás do ator.

A falta de interação também pode ser vista na fotografia em que as manequins posam com Ricardo Montalban (1920-2009), ator de origem mexicana que começou a atuar no cinema em 1941 e que posteriormente enveredou para os musicais da Broadway e produções televisivas. Na imagem, o latin lover como destaca a legenda, que estrelou longas de sucesso como Sayonara Uoshua Logan, 1957), mostra sua casa à Mila e Betina. Os três posam à beira da piscina, Mila e Betina encostam na pilastra enquanto o ator aparece mais à frente, a certa distância, com as mãos nos bolsos do terno e as pernas levemente separadas.
75. A Guerra do Vietnã aconteceu entre 1959 e 1975, e foi um conflito entre os dois governos estabelecidos que lutavam pela unificação do país sob sua liderança. O envolvimento dos Estados Unidos e a motivação ideológica do conflito são consequências das tensões da polarização da Guerra Fria (1947-1991). 76. Cf. Adamatti (2008). 


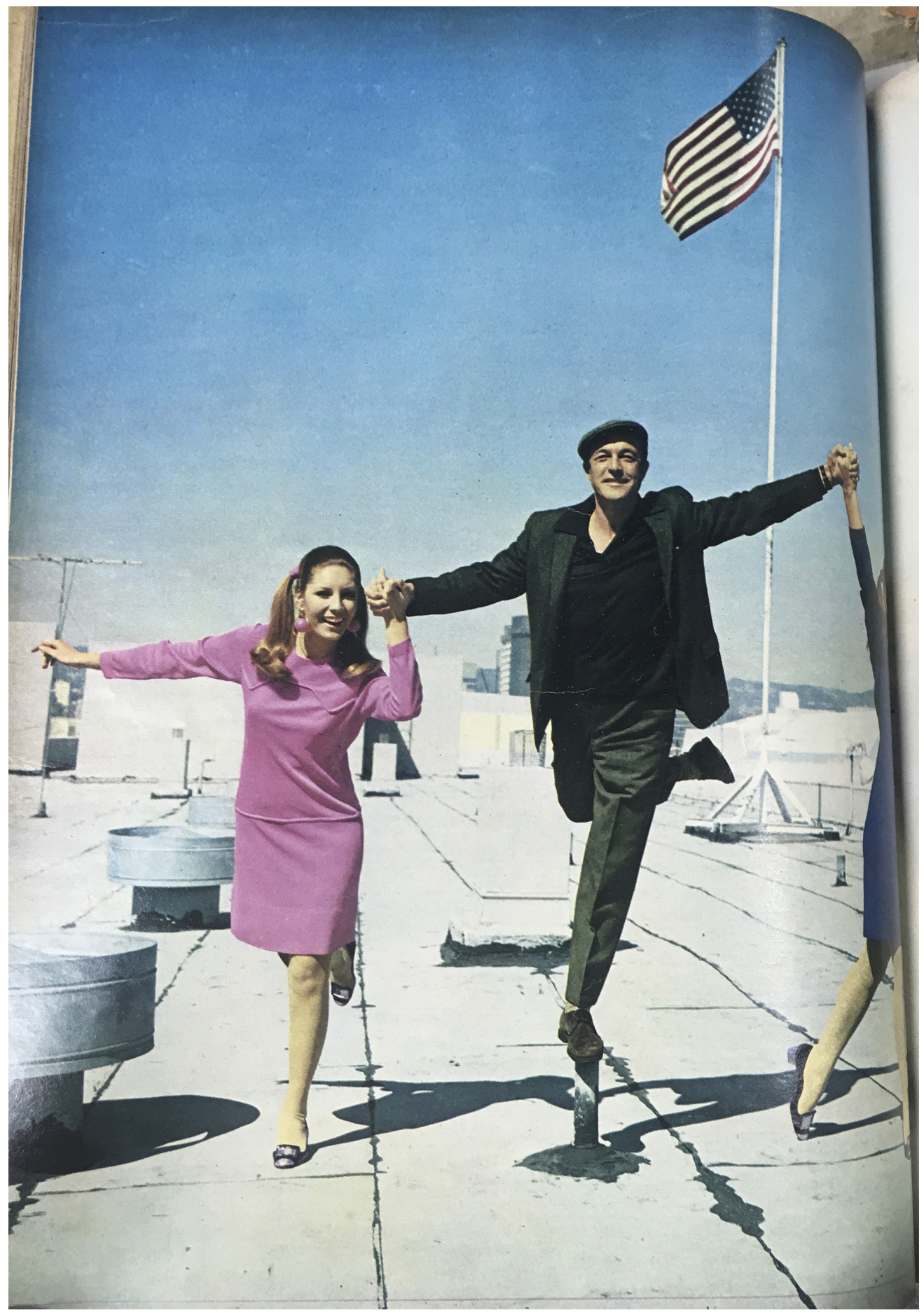

Figura 4 - Mila e Betina fotografadas ao lado de Gene Kelly. Claudia, n. 67, abril de 1967. Foto: Lew Parrella. Fonte: Claudia. Acervo Biblioteca Nacional - Rio de Janeiro. 
A exceção aparece na fotografia em que Gene Kelly (1912-1996) é fotografado com Mila e Betina (apesar desta ter sido cortada da fotografia e aparecer somente seu braço) no telhado dos estúdios da Fox. Apesar de estar entre os astros mais velhos do editorial, o ator que ficou conhecido por dançar e cantar em seus filmes e que estrelou e dirigiu o musical Cantando na chuva (1952) - um dos grandes clássicos do cinema mundial - é retratado de mãos dadas com as manequins, como se estivessem correndo ou dançando. Ao fundo, podemos ver o horizonte e a bandeira dos Estados Unidos. A presença da flâmula é simbólica do contexto vivido pelo Brasil neste período. O país, que vivia sob influência do american way of life, tinha os norte-americanos como referência de desenvolvimento e modernidade, absorvendo valores difundidos pelos "vizinhos". Nesta conjuntura, através da lógica do liberalismo, a liberdade tornou-se, durante os anos 1950 e 1960, o principal valor cultuado pela sociedade, sendo cada vez mais divulgado pelos meios de comunicação, que informavam a seu público que suas liberdades consistiam em trabalhar, produzir, vender e comprar. ${ }^{77}$ Logo, a liberdade passou a ser associada ao ato de consumir:

A liberdade da qual os anúncios falavam era, pois, a liberdade do lazer, da busca do prazer, da satisfação de desejos, da movimentação dos membros. Somava-se a esta imagem da liberdade o fato de que, diante da infinidade de mercadorias e de marcas que começavam a ser lançadas no mercado, o consumidor passava a experimentar cotidianamente o imperativo da escolha, já que consumir implicava, cada vez mais, ter de optar por uma ou outra mercadoria. Ocorre que numa sociedade capitalista, na qual é grande o número de objetos despejados no mercado que se prestam à mesma utilidade, o indivíduo precisa apoiar as suas decisões de consumo em critérios que ultrapassam o valor de uso dos objetos. Tais critérios são estritamente subjetivos e orientam-se em função do significado pessoal que os objetos adquirem para o consumidor. ${ }^{78}$

Deste modo, podemos interpretar a presença da bandeira associada à fotografia mais dinâmica do editorial como uma forma de simbolizar essa liberdade e ao mesmo tempo transmitir este significado para a roupa apresentada. Além disso, também é possível inferir que a imagem transmite uma ideia de liberdade de movimento, pois, além de ser uma pose menos estática em relação ao restante do editorial, a modelo e o astro aparecem sorrindo. 


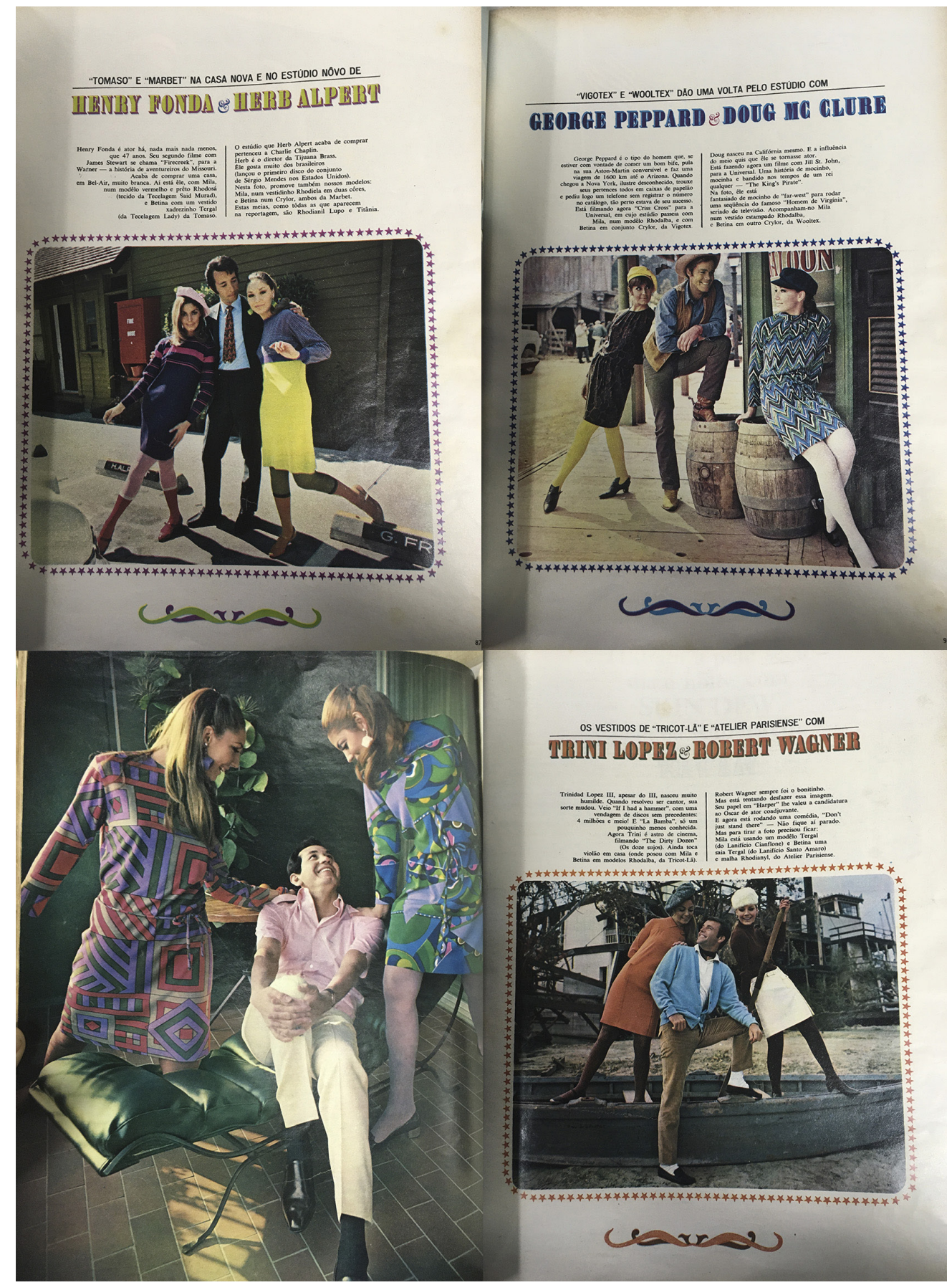

Figura 5 - Mila e Betina posam ao lado de Herb Alpert, Doug McClure, Trini Lopez e Robert Wagner, respectivamente. Claudia, n. 67, abril de 1967. Foto: Lew Parrella. Fonte: Claudia. Acervo Biblioteca Nacional - Rio de Janeiro. 
Quando os astros são mais jovens e considerados galãs, é possível notar que a fotografia apresenta maior interação destes com as modelos, mas, ainda assim, permanece um contato leve e sutil (Figura 5). Mila e Betina são abraçadas pelo músico Herb Alpert (1935-), líder da banda Herb Alpert \& the Tijuana Brass e compositor de sucessos como "Wonderful world" (1960) e "The taste of honey", canção que arrebatou três Grammy Awards"79 em 1966. Segundo a legenda, Alpert acabara de comprar o estúdio que pertenceu a Charlie Chaplin (19881977) para sediar sua gravadora A\&M Records (1962-1999). O texto também aponta a relação do músico com os brasileiros, de quem diz gostar muito. A legenda informa ainda que Alpert foi responsável por gravar o primeiro disco de Sérgio Mendes (1941) nos Estados Unidos, tentando, dessa forma, reforçar a ideia de internacionalização da cultura brasileira, em especial de Sérgio Mendes que em 1963 e 1964 ganhou maior visibilidade a partir de suas participações nos shows da Rhodia - que eram apresentados na Feira Nacional da Indústria Têxtil (Fenit) e também em diversas localidades do Brasil e do mundo.

Herb Alpert foi fotografado entre as manequins, abraçando-as por trás e olhando para Betina, que assim como Mila encara a câmera. Para Erving Goffman, quando este gesto de abraçar os ombros ocorre entre pessoas de sexos diferentes, indica uma relação de posse. ${ }^{80}$ Mais uma vez, somos apresentados a poses estáticas em que a postura dos pés elevados se mantêm, porém, podemos notar que Mila inclina seu corpo para trás, aproximando seu tronco do músico e mantendo as pernas mais afastadas, numa posição pouco natural ou confortável.

Quanto à locação, podemos inferir que a fotografia foi realizada no estacionamento do estúdio de Herb Alpert, pois é possível ver a marcação do estacionamento com o nome do cantor. A escolha do cenário não é aleatória, uma vez que faz parte da encenação da fotografia de moda e atende aos propósitos do produto anunciado, do fotógrafo e do veículo no qual o editorial seria publicado. ${ }^{81}$ Deste modo, podemos supor que a foto foi feita em frente ao nome de Herb Alpert para reforçar sua importância e o acesso que a revista e o anunciante têm a esse universo.

Mila e Betina também são fotografadas acompanhadas por Doug McClure (1935-1995), ator que, apesar de ter iniciado sua carreira no cinema, conquistou fama na TV, com a série de faroeste $O$ homem de Virgínia (1962-1971), uma das mais duradouras do gênero, em que interpretou o vaqueiro Tampas. De acordo com a legenda, é no cenário desta produção que a foto foi realizada. Vestido de cowboy, Doug McClure posa com um dos pés sobre um barril, apoiando o corpo sobre a perna e olhando para Betina, que, sentada no barril à frente, parece devolver o olhar. Atrás do ator, Mila é apresentada em uma postura diagonal, em que seu tronco, apoiado em uma das mãos, está mais próxima do astro, e as
79. Principal cerimônia de premiação que elege os profissionais da indústria musical. Ocorre anualmente desde 1959.

80. Cf. Goffman (1979).

81. Rainho (2014). 
82. Figueiredo (1998, p. 156).

83. Cf. Veblen (1974).

84. Informação retirada do site <https://imdb.to/3shfule. $>$ pernas mais afastadas. A modelo também olha para McClure, porém a expressão de Betina nos remete a um semblante de sedução. Porém, é preciso ressaltar que se trata de uma sedução comportada, restrita apenas à troca de olhares.

Também é possível notar maior interação na fotografia em que Trini Lopez (1937-2020) aparece ao lado das modelos. Famoso por hits como "La bamba" (1958) e "If I had a hammer" (1963) que o alçaram às paradas de sucesso em vários países. $O$ cantor, que também enveredou para o cinema participando de filmes como Os doze condenados (Robert Aldrich, 1967), aparece sentado em uma espécie de divã, em postura relaxada e envolto pelas manequins, como se estivessem conversando. A legenda, que reforça a origem humilde do astro, informa que a foto foi clicada em sua casa. De um lado temos Mila, com um joelho sobre o assento, e do outro, Betina, que recosta na borda mais alta do sofá. Ambas pousam as mãos nos ombros do astro.

Assim como na fotografia de Trini Lopez, as modelos também tocam Robert Wagner (1930-), que é fotografado ao lado das manequins. $\bigcirc$ ator, que teve sua estreia no cinema em 1951, ganhou seu primeiro papel de protagonista em 1953 com o longa Rochedos da morte (Robert D. Webber), mas foi com o papel do coadjuvante Allan Target em Caçador de aventuras (Jack Smight) que foi indicado ao Oscar em 1966 - fato ressaltado na legenda. O cenário, que não é indicado na legenda, revela que a fotografia foi realizada em um litoral, uma vez que as manequins e o astro posam com um pequeno barco ancorado na areia. Enquanto $o$ ator apoia apenas um pé na canoa, as meninas são clicadas de pé em sua borda. Mila e Wagner trocam olhares e sorrisos, e ela se apoia em seu ombro. Já Betina aparece segurando o remo.

Aqui podemos interpretar o barco como uma representação do lazer distintivo, disponível para uma minoria que possuía os meios de desfrutá-lo. Com a popularização dos "bens industriais, os indivíduos adquirem também tempo. Tempo 'livre' para dedicar ao lazer, que nada mais era senão o desfrute do novo padrão de vida que a industrialização [...] tornava viável para alguns segmentos da população" ${ }^{82}$ Deste modo, podemos suscitar a concepção de Thorstein Veblen em A teoria da classe ociosa, onde o autor versa sobre o lazer e o consumo ostensivos das classes altas como forma de distinção. ${ }^{83}$ De acordo com o autor, estas classes realizavam atividades de lazer dotadas de status e poder como forma de distinguir-se dos demais, ostentando um determinado estilo de vida.

Também podemos observar o lazer ostensivo na Figura 6. Mila e Betina posam juntamente a Steve McQueen (1930-1980) ao lado de um carro esporte. $O$ ator apelidado de king of coo/84 se consagrou em Hollywood com suas 
atuações nos filmes Sete homens e um destino (John Sturges, 1960) e Fugindo do inferno (John Sturges, 1963). McQueen aparece de braços cruzados e pernas cruzadas próximo ao automóvel, enquanto as modelos posam um pouco à sua frente, mais próximas da câmera, com Betina, à direita, tocando o carro. A legenda destaca que o astro possui mais cinco carros além do que aparece na fotografia, somados a seis motocicletas e uma caminhonete, reforçando o consumo de bens de luxo desta classe. Além disso, pode-se dizer que o automóvel é um dos principais símbolos do american way of life. ${ }^{85}$

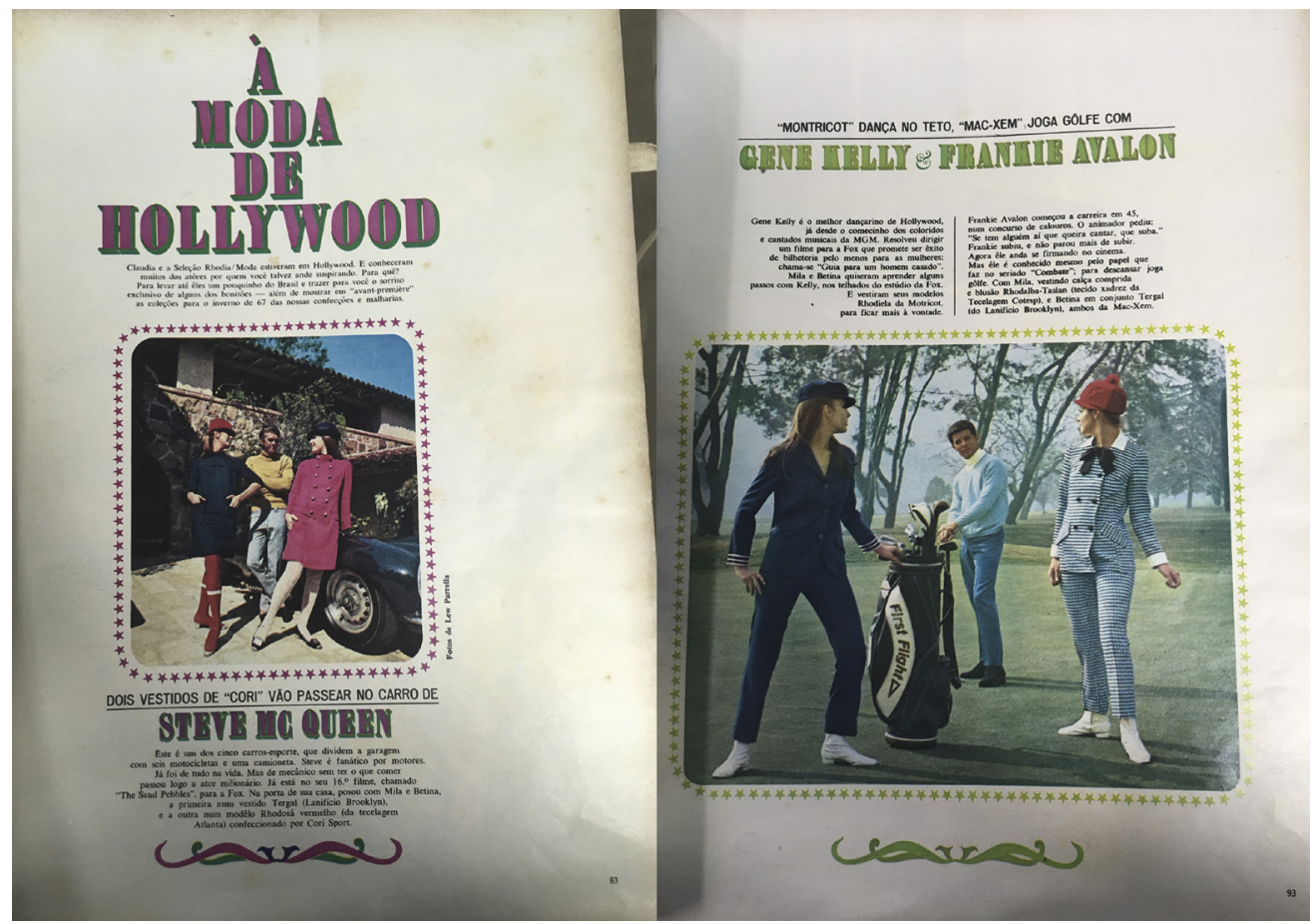

Figura 6 - Mila e Betina são fotografadas com Steve McQueen e Frankie Avalon. Claudia, n. 67, abril de 1967. Foto: Lew Parrella. Fonte: Claudia. Acervo Biblioteca Nacional - Rio de Janeiro.

Do mesmo modo, podemos distinguir as manequins ao lado de Frank Avalon (1939-) em um campo de golfe. Cantor e ator, o astro emplacou diversas canções entre os primeiros lugares das paradas pelo mundo, mas seu reconhecimento no cinema se deu pela sua ałuação em $O$ álamo (1960), de John Wayne. Na fotografia, Avalon posa apoiando as mãos em um taco de golfe, enquanto Mila, que toca uma bolsa com os equipamentos, e Betina estão localizadas mais à frente, olhando para o astro. $\bigcirc$ esporte, que é descrito na legenda como atividade usada pelo ator para descansar, é considerado uma prática relacionada às classes abastadas. 


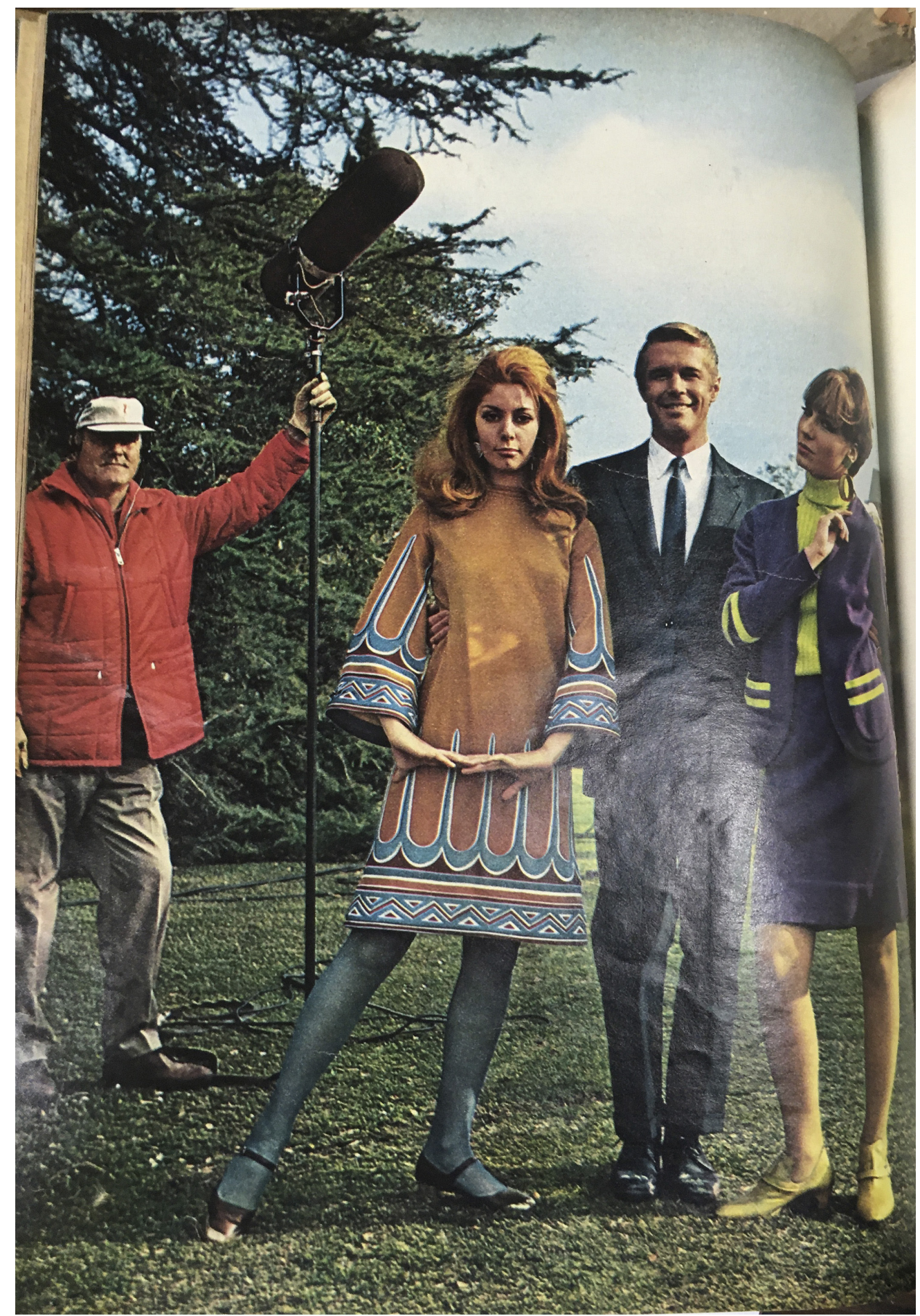

Figura 7 - George Peppard ao lado de Mila e Betina. Claudia, n. 67, abril de 1967. Foto: Lew Parrella. Fonte: Claudia. Acervo Biblioteca Nacional - Rio de Janeiro. 
Também podemos ver uma representação de distinção na Figura 7, que retrata George Peppard (1928-1994), protagonista do clássico cinematográfico Bonequinha de luxo (Blake Edwards, 1961), sucesso de crítica e de público. Enquanto o astro abraça Mila e Betina, um contrarregra, que não é identificado ou sequer mencionado, aparece mais atrás. A locação, segundo a legenda, consiste no estúdio da Universal. Talvez a presença do contrarregra seja uma forma de indicar isso imageticamente, uma vez que o cenário é composto por apenas um campo aberto. Entretanto, também pode indicar uma forma de comparar o funcionário com as manequins e o astro, ressaltando o estilo de vida glamouroso de Hollywood. $\bigcirc$ texto nos faz crer nesta segunda hipótese, pois ela diz que "George Peppard é o tipo de homem que, se estiver com vontade de comer um bom bife, pula na sua Aston-Martin conversível e faz uma viagem de $1.600 \mathrm{~km}$ até o Arizona". ${ }^{86}$

Embora alguns astros da TV apareçam ao longo do editorial, o universo das séries televisivas também é explorado nas fotografias (Figura 8). Mila e Betina posam ao lado de James Darren (1936), astro de Túnel do tempo (1966-1967), produção que ganhou o prêmio $\mathrm{Emmy}^{87} \mathrm{em}$ 1967. A fotografia foi realizada no cenário do programa, e o ator, que foi clicado com a roupa que usava na abertura da série, posa de maneira despojada junto a um spot de luz, enquanto Mila e Betina posam com seus "terninhos do século XX", como descreve a legenda.
86. Claudia (1967, p. 90).

87. Principal premiação atribuída a programas e profissionais televisivos. Ocorre desde 1949.
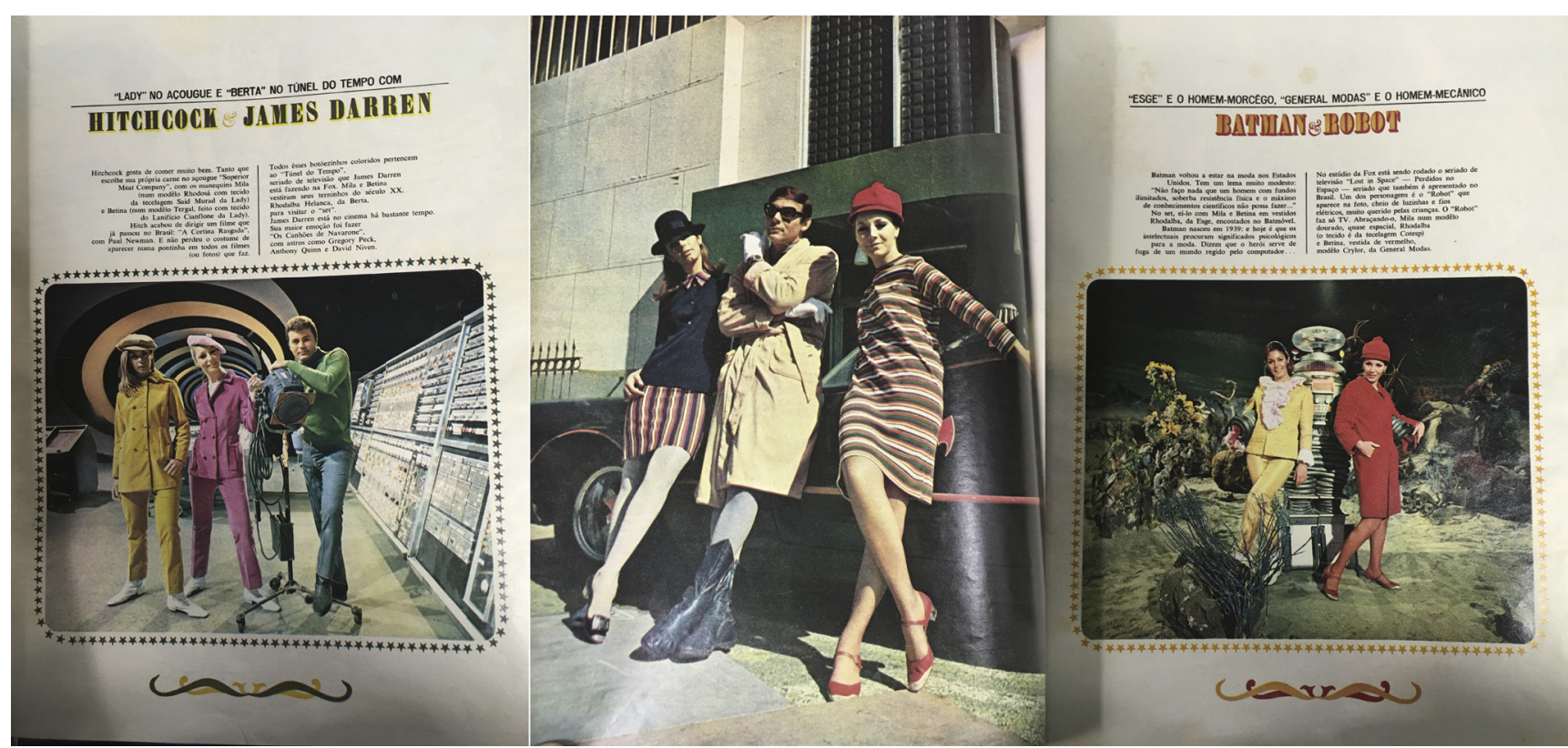

Figura 8 - Mila e Betina ao lado de James Darren, Adam West e Robot. Claudia, n. 67, abril de 1967. Foto: Lew Parrella. Fonte: Claudia. Acervo Biblioteca Nacional - Rio de Janeiro. 
88. Cf. Gatti; Aurélio (2002)

89. Competição iniciada entre os Estados Unidos e a União Soviética durante a Guerra Fria (1957-1975) pela hegemonia da tecnologia e exploração espacial (Hobsbawm, 1995).

90. Mendes; Haye (2009).

91. Ortiz (1988).

92. Bonadio (2014).

93. Claudia (1967, p. 87).
Batman e o batmóvel também aparecem acompanhados de Mila e Betina. E aqui falamos Batman e não seu intérprete Adam West (1928-2017), pois diferentemente dos outros astros, o título e a legenda não trazem o nome do ator, e sim do personagem. De acordo com Mário Gatti e Bigu, 88 publicitários que trabalhavam com a Rhodia no período, o ator se negou a usar máscara, pois queria ser reconhecido como Adam West e não como o homem morcego, porém, apesar do trench-coat, é possível ver as botas e luvas usadas pelo personagem. A série televisiva Batman e Robin foi exibida entre os anos 1966 e 1968, e em seu ano de estreia foi indicada a três Emmys.

Outro personagem da TV presente no editorial é o Robot de Perdidos no espaço (1965-1968). Na fotografia realizada no set do programa de TV, Mila e Betina são envolvidas pelos braços do robô e o abraçam de volta. A série foi exibida no Brasil pela TV Record e seu sucesso foi tão grande que foi reexibida pela Rede Globo nos anos 1970 e pela TV Tupi na década de 1980, e em 2018 ganhou uma nova versão realizada pela Nefflix. A legenda anuncia que Robot era o personagem preferido das crianças, o que pode sugerir que sua presença no editorial seja uma forma de ressaltar o ideal de domesticidade que tem a maternidade como principal objetivo a marcar a "mulher moderna" de Claudia. Também podemos compreender a presença do robô como uma alusão à corrida espacial ${ }^{89}$ que permeou a década de 1960 e que influenciou a cultura e a moda do período, infundindo no imaginário da sociedade valores relacionados ao futuro e à ficção científica. ${ }^{90}$

A presença destes programas de grande sucesso da TV em meio ao editorial de Hollywood nos mostra as transformações que os meios de comunicação, a industrialização e a urbanização haviam passado no Brasil, uma vez que é a partir do início dos anos 1960 que a televisão havia começado a se popularizar no país. ${ }^{91}$

Entretanto, embora os músicos e atores citados fizessem sucesso, nenhum deles era um herói subversivo ou músico ligado ao rock'n'roll e à contracultura que se popularizavam entre os jovens durante os anos 1960. O que reforça como a revista, apesar de afirmar estar alinhada com os novos tempos, prefere se manter em uma perspectiva mais tradicional e clássica em relação aos papéis binários de gênero.

Logo, é possível inferir como Claudia e Rhodia utilizam uma forma de transferência de significado ${ }^{92}$ ao utilizar astros consagrados do cinema, da TV e da música e seu universo de luxo e glamour para atribuir status à revista, às roupas feitas com fibra sintética e, consequentemente, às confecções responsáveis pela realização das roupas, uma vez que seus nomes aparecem em todos os títulos e legendas, como, por exemplo, "Tomaso e Marbet na casa nova e no estúdio novo de Henry Fonda e Herb Alpert". ${ }^{93}$ 
No conjunto de confecções que trabalhavam com a cadeia Rhodia - que ia da estamparia

Através da revista, a leitora saberia se informar sobre onde adquirir aquelas roupas e como usá-las, uma vez que o editorial demonstra sua versatilidade ao sugerir que as peças serviriam para frequentar e desfrutar o luxo expresso nas fotografias. Assim, as produções de Claudia e Rhodia, além de legitimarem a moda feita no Brasil, funcionavam como um guia de compras. Como cada confecção trabalhava como uma "especialidade", a leitora saberia onde procurar caso quisesse um modelo estampado ou listrado, por exemplo.

\title{
A "MULHER MODERNA" VAI A HOLLYWOOD
}

Entre os anos 1950 e 1960, a fotografia de moda passa por transformações significativas:

\begin{abstract}
Se examinarmos as fotografias de moda dos anos 1950, veremos que elas normalmente mostravam mulheres na casa dos 20 anos em ambientes de classe média, mas o centro de interesse eram as roupas. Nos anos 1960, passou a haver uma ênfase claramente mais forte na juventude - e, notavelmente, uma quantidade muito maior de pele era mostrada. Desde então esse desenvolvimento só se intensificou, um traço constante sendo que as próprias roupas foram cada vez mais relegadas ao segundo plano na fotografia de moda. Em vez de apresentar roupas, buscava-se cada vez mais apresentar uma imagem em que o corpo do modelo é portador de valores simbólicos. ${ }^{95}$
\end{abstract}

Modificações no que se refere ao tema e às produções das imagens também permeiam a fotografia de moda neste período. As modelos passaram a ser abordadas fora do cenário doméstico e do estúdio, prevalecendo o estilo em detrimento da divulgação do produto, com maior ênfase no movimento e na liberdade corporal. Porém, Maria do Carmo Rainho destaca que essas novas formas de representação visual não se deram de forma abrupta, uma vez que eram sintomáticas de mutações graduais que ocorreram na esfera da cultura, o que fica evidente no editorial analisado neste trabalho. ${ }^{90}$

Deste modo, a segunda metade da década de 1960 inaugura na fotografia a representação de uma nova mulher na moda, denominada "mulher dinâmica", 
97. Ibid.

98. Ibid. (p. 131).

99. Cf. Rainho (2014).

100. Ibid.

101. Cf. Goffman (1979) que rompe com a chamada "mulher-ornamento", definida pela autora como aquela que se vestia e se comportava visando a aprovação masculina, dependia do marido e consumia alta-costura. Ela era retratada nas imagens sempre em pé, com cabelos e roupas impecáveis e poses rígidas. Já a nova mulher, jovem, esportiva, sexy, que trabalha ou frequenta a universidade, circula pelos espaços de sociabilidade acompanhada de amigas e veste-se de maneira autônoma, é representada pela fotografia de moda em movimento em locações externas, públicas ou privadas, como ruas, parques e praias, sozinha ou em dupla, próxima a carros, barcos ou motos, elementos que denotam movimento. ${ }^{97}$

Em "À moda de Hollywood" podemos ver de fato algumas transformações, como a ambientação fora de estúdios e locais domésticos. Mas, embora já comece a haver maior foco no estilo, as poses, que ainda mostram bastante as roupas, ainda são predominantemente estáticas e ainda estão bem próximas das posturas contidas dos anos 1950 referentes a esse modelo da mulher-ornamento.

Performances de gênero calcadas na feminilidade, na docilidade, numa naturalidade que é cuidadosamente construída, envolve práticas de controle do corpo, o uso de roupas "corretas", a adequação das vestimentas. A ritualização da feminilidade se dá a ver por protocolos demarcados: do olhar ao posicionamento de braços, pernas e pés; da escollha das peças à forma de portá-las, constrói-se um modelo de gênero que se revela reiterativo porque [...] embora os conteúdos da moda se alterem semestralmente, as formas de apresentação das vestimentas são as mesmas. ${ }^{98}$

Deste modo, apesar do editorial trazer roupas mais despojadas como calças, comprimentos mais curtos e formas retas, as manequins ainda apresentam poses predominantemente estáticas associadas à década anterior e que reforçavam o ideal de feminilidade dos anos 1950. Uma postura referente a este período que predomina no editorial é "a arte de elevar o pé", que segundo Maria do Carmo Rainho ${ }^{99}$ é inspirada pelas bailarinas e sugere encantamento, recato e graciosidade. Nesta pose, as modelos apresentam seus pés delicadamente posicionados com uma leve elevação nas pontas (Figura 9).

As mãos das manequins também são representadas de forma estática (Figura 10). Na maioria das fotos podemos vê-las com os braços estendidos ao lado do corpo, sinal de recato, 100 ou tocando delicadamente os bolsos e detal hes das roupas, dos seus cabelos, partes do cenário, como o carro, a bolsa de golfe e a pilastra da casa de um astro, ou até mesmo os atores e músicos. Erving Goffman denomina este gesto como "toque feminino", por meio do qual as mulheres são retratadas usando suas mãos para segurar ou acariciar um objeto. ${ }^{101}$ 
Diferentemente do toque utilitário ou da simples manipulação de um item, esta pose é um modo de destacar e dar valor ao que é tocado, sendo também uma forma de guiar o olhar do espectador para determinado detalhe.

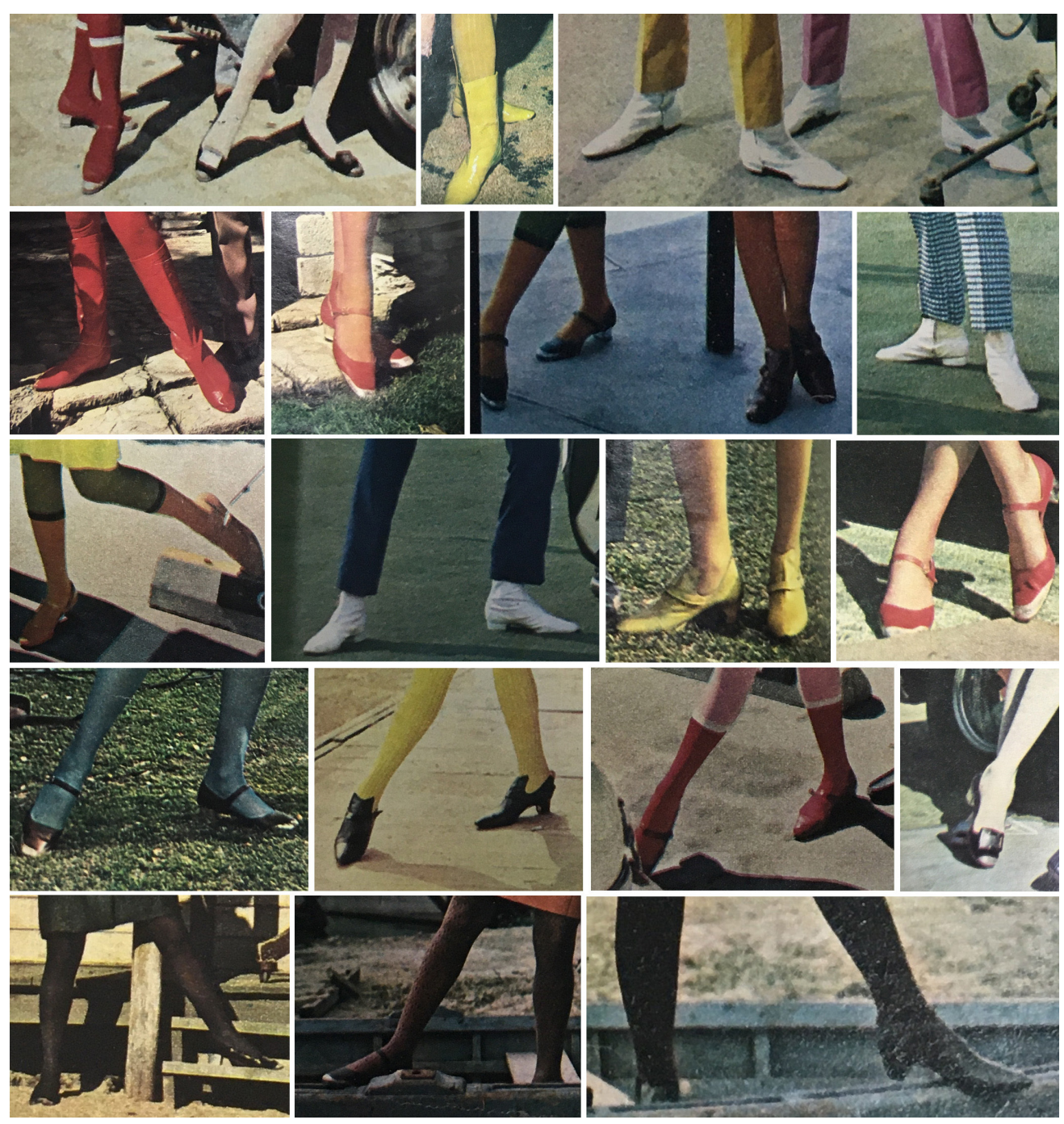

Figura 9 - Bloco de imagens que demonstra a permanência dos pés em pose recatada das modelos. Fonte: Claudia. Acervo Biblioteca Nacional - Rio de Janeiro. 
102. Lipovetsky (2009, p. 133).

103. Ibid. (p. 139)

Figura 10 - Bloco que demonstra o "toque feminino". Fonte: Claudia. Acervo Biblioteca Nacional - Rio de Janeiro.
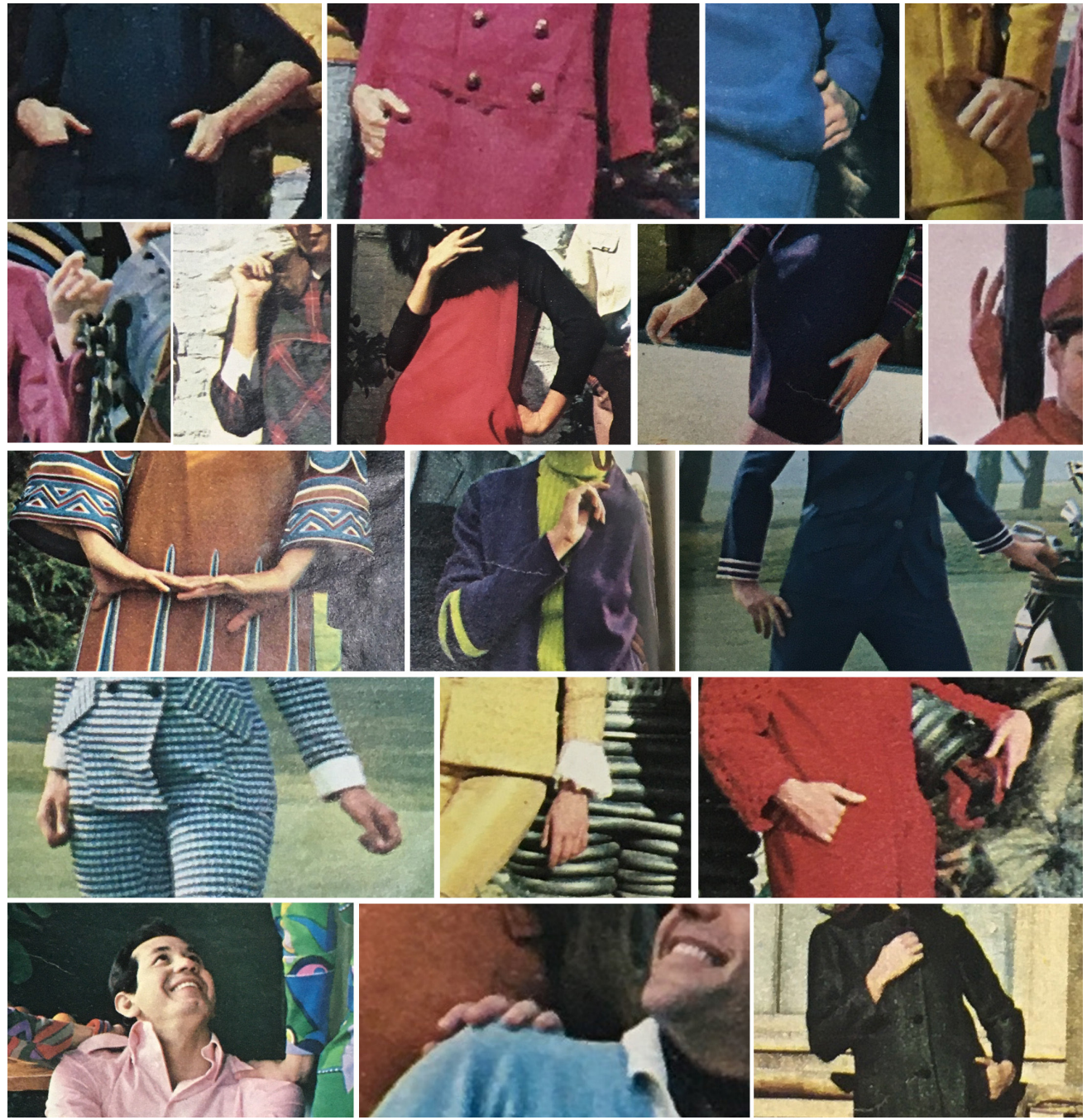

Neste período, as transformações no sistema da moda acarretadas pela popularização do prêt-à-porter em consonância com a emergência de uma sociedade cada vez mais voltada para o novo e para o consumo coincidiram com o surgimento de uma cultura juvenil, "fonte do fenômeno 'estilo' dos anos 1960". 102

universo dos objetos, dos media, do lazer permitiu a emergência de uma cultura de massa hedonista e juvenil que está no coração do declínio final da moda suntuária. $\bigcirc$ impulso de uma cultura jovem no decorrer dos anos 1950 e 1960 acelerou a difusão dos valores hedonistas, contribui para dar uma nova fisionomia à reinvindicação individualista. Instalou-se uma cultura que exibe o não conformismo, que exalta valores de expressão individual, de descontração, de humor e de espontaneidade livre. [...] A moda ganhou uma conotação jovem, deve exprimir um estilo de vida emancipado, liberto das coações, desenvolto em relação aos cânones oficiais. ${ }^{103}$ 
Assim, "na década de 1960 a roupa da moda também atua na configuração da juventude como atributo. As fotografias de imprensa, em especial as fotografias de moda, vão conformar estereótipos, mitos e modelos juvenis e disseminar a noção de juventude como valor" transformando a minissaia em traje-símbolo do período. ${ }^{104}$ Criada por Mary Quant (1934-) em 1955, a peça transmitia, quando combinada com suéteres justos e botas de cano alto, um visual infantilizado, que permaneceria em voga até 1967. ${ }^{105}$ Até a década de 1960, o comprimento curto era usado em ocasiões excepcionais relacionadas à necessidade de liberar o corpo feminino para a prática de esportes ou para o uso de transportes, porém, a partir desta década, as minissaias tomariam as ruas e evidenciariam a liberdade sexual:
104. Rainho (2014, p. 255). 105. Mendes; Haye (2009). 106. Ibid. (p. 230).

São um artificio erótico usado por mulheres que possuem o controle do próprio corpo, sendo difícil não associar sua disseminação ao advento da pílula anticoncepcional. Roupa da muIher jovem, solteira, sexualmente ativa, a minissaia está na contramão da maternidade, da feminilidade comportada, abre um abismo entre sua portadora e as mulheres de outras gerações A mini não é a adaptação de uma roupa a uma determinada faixa etária: foi criada para atender a uma classe de idade que até então não detinha a posse da moda. ${ }^{106}$

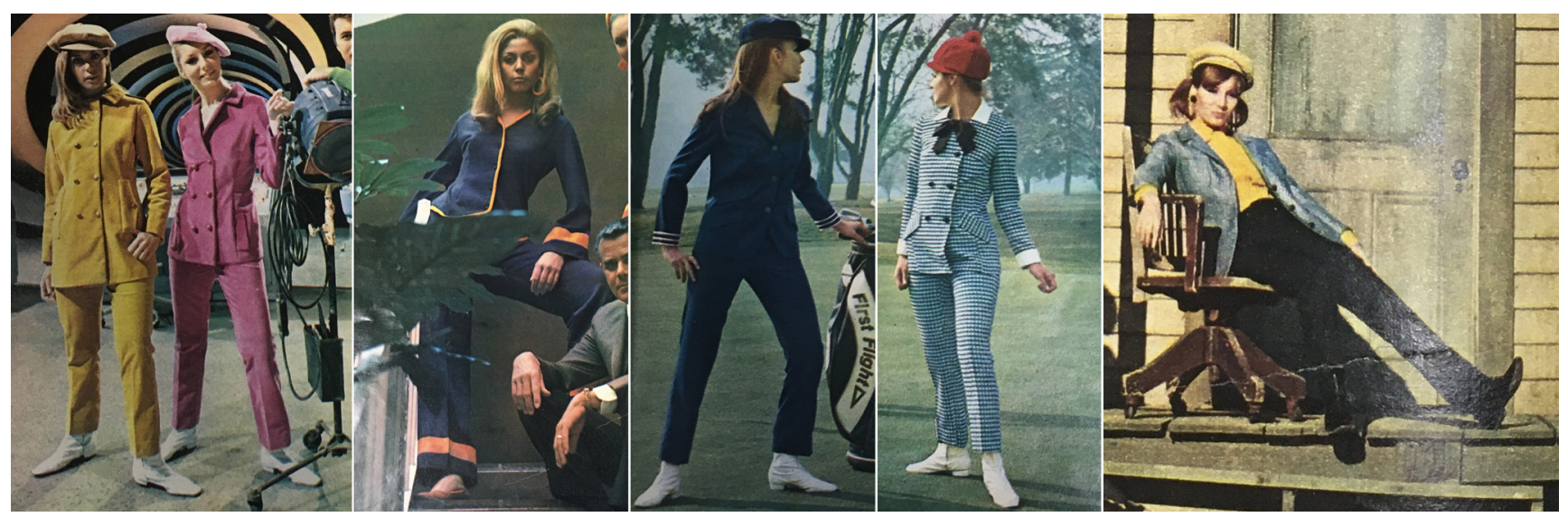

Figura 11 - Bloco que evidencia as poses das modelos enquanto usam calças compridas. Fonte: Claudia. Acervo Biblioteca Nacional - Rio de Janeiro.

Entre as dezesseis fotografias trazidas pelo editorial, temos o total de 32 looks, dentre eles é possível contabilizar 26 com comprimentos curtos, sejam saias ou vestidos, e seis com calças compridas. Embora as minissaias predominem nas imagens em questão, o que vemos não é o visual despojado da juventude descrito acima. As modelos que a usam ainda aparecem em poses contidas e recatadas associadas à jovem senhora dos "anos dourados", e o traje é predominantemente acompanhado de meias-calças opacas. Brancas e estampadas para o verão ou 
107. Ibid.

108. Rainho (2014, p. 229).

109. Rainho (2014, p. 347).

110. Ibid. coloridas em fios grossos para o frio, as meias-calças são lembretes de que a popularização da minissaia não era sinônimo de pernas de fora. ${ }^{107}$

As calças compridas também foram trajes excepcionais para as mulheres durante muito tempo e eram usadas em circunstâncias específicas, como práticas desportivas, atividades de lazer e férias. Porém, a partir da segunda metade da década de 1960, a peça começou a ganhar novos espaços e tomar as ruas. Insistir no lançamento da calça,

era, portanto, tornar regra algo que até então, era usado circunstancialmente, e evidenciava uma sintonia com mulheres jovens e dinâmicas, que estavam inseridas no mercado de trabatho, possuíam acesso ao ensino superior, experimentavam uma sociedade que exigia roupas menos formais. Há um aspecto simbólico nas propostas de adoção de calças compridas uma vez que elas sempre estiveram associadas aos momentos em que a mulher se destacou por exercer atividades profissionais, usando uma vestimenta que a igualava ao homem. ${ }^{108}$

A peça era a antítese do new look da década de 1950, pois expressava poder, igualdade, controle do corpo e da sexualidade, apontando para uma maior ocupação de espaço pelas mulheres. Assim, as calças "vão sendo progressivamente adotadas pelas brasileiras ao longo da segunda metade dos anos 1960, inclusive em situações mais formais; contudo ainda eram vistas como trajes de exceção, como uso codificado e restrito. É a juventude que vai fazer das calças uma peça de uso contínuo". 109

Através das fotografias de moda, as calças eram associadas à sensualidade latente, já que poses com apelo ao erotismo eram empregadas para assegurar que as mulheres que as usassem continuavam femininas. ${ }^{110}$ Contudo, as calças compridas do editorial não são acompanhadas por essa representação corporal mais dinâmica, jovem e com apelo sensual, pois seguem expostas em poses recatadas e rígidas (Figura 11). A fotografia em que podemos ver uma manequim em apresentação mais despojada e relaxada se refere à imagem na qual não há nenhum ator ou personagem posando com a modelo (Figura 12).

Na Figura 12, Mila e Betina aparecem em um cenário de "velho oeste". Enquanto a aquela, fotografada usando um vestido, aparece em postura mais tradicional, esta posa de forma completamente oposta. Usando calças compridas, a manequim aparece sentada em uma cadeira do cenário de maneira despojada e até "largada", com pernas abertas e uma mão apoiada no encosto na cadeira. Esta pose também se enquadra na fala de Maria do Carmo Rainho ao descrever os atos performativos presentes nas imagens de mulheres usando calças compridas: 
"Os membros não estão disciplinadamente posicionados, as pernas não estão fechadas e a área genital não está dissimulada". 111

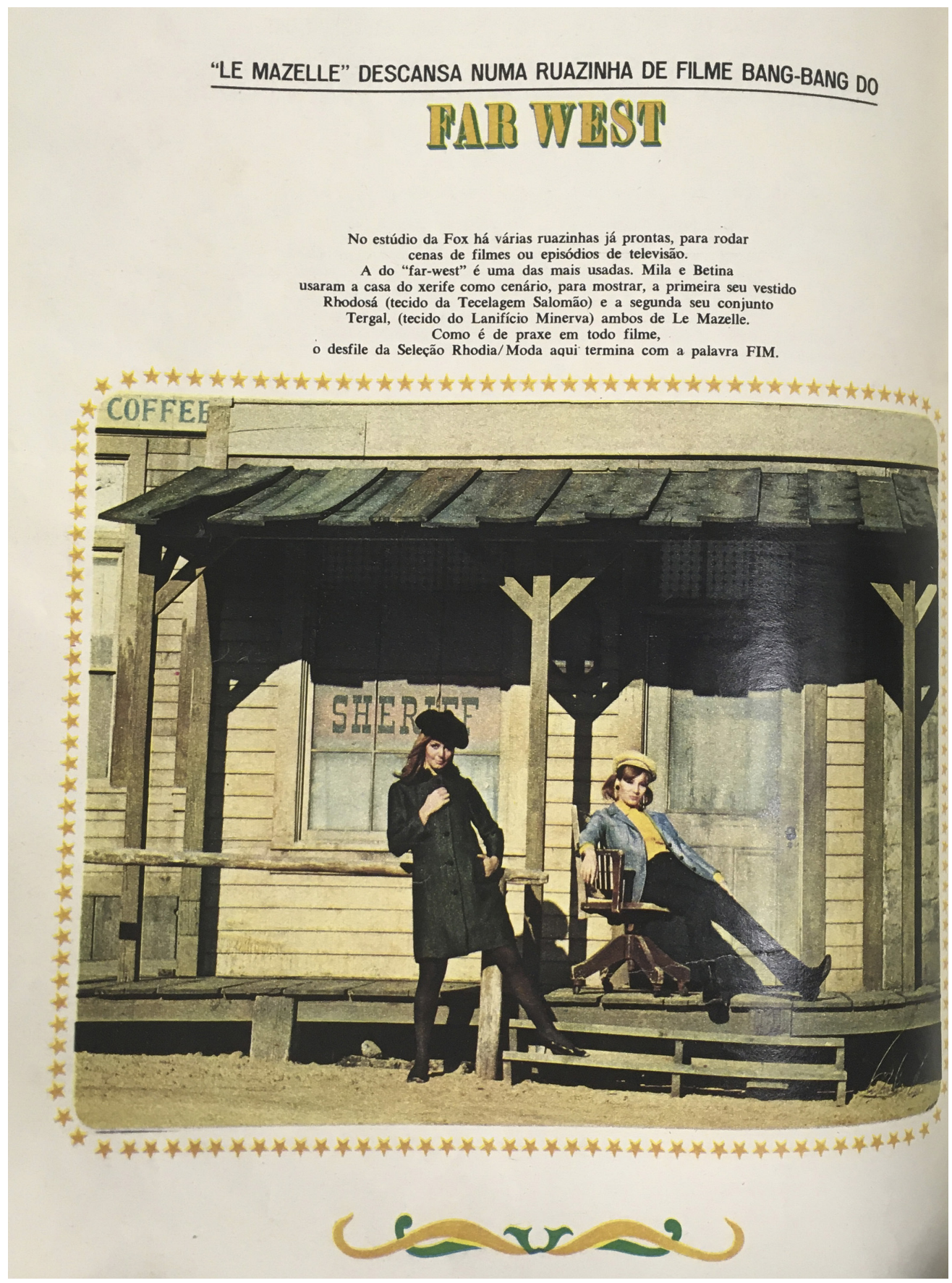

Figura 12 - Mila e Betina em Far West. Claudia, p. 98, abril de 1967. Foto: Lew Parrella. Fonte: Claudia, n. 67, abril de 1967. Acervo Biblioteca Nacional - Rio de Janeiro. 
As botinhas brancas da Figura 13 também estavam voga naquele período. Criadas por André Courrèges (1923-20 16), em 1965, os sapatos eram chatos e com biqueira quadrada, truncada. $\bigcirc$ estilista, que se inspirava no vestuário esportivo e nos trajes espaciais, via a cor branca como símbolo da juventude e do otimismo. ${ }^{112}$ No editorial, as botinhas são usadas por Mila e Betina combinadas com conjuntos de calça de alfaiataria e paletós transpassados e longos com debruns nos bolsos, looks criados pelo designer em meados dos anos 1960.

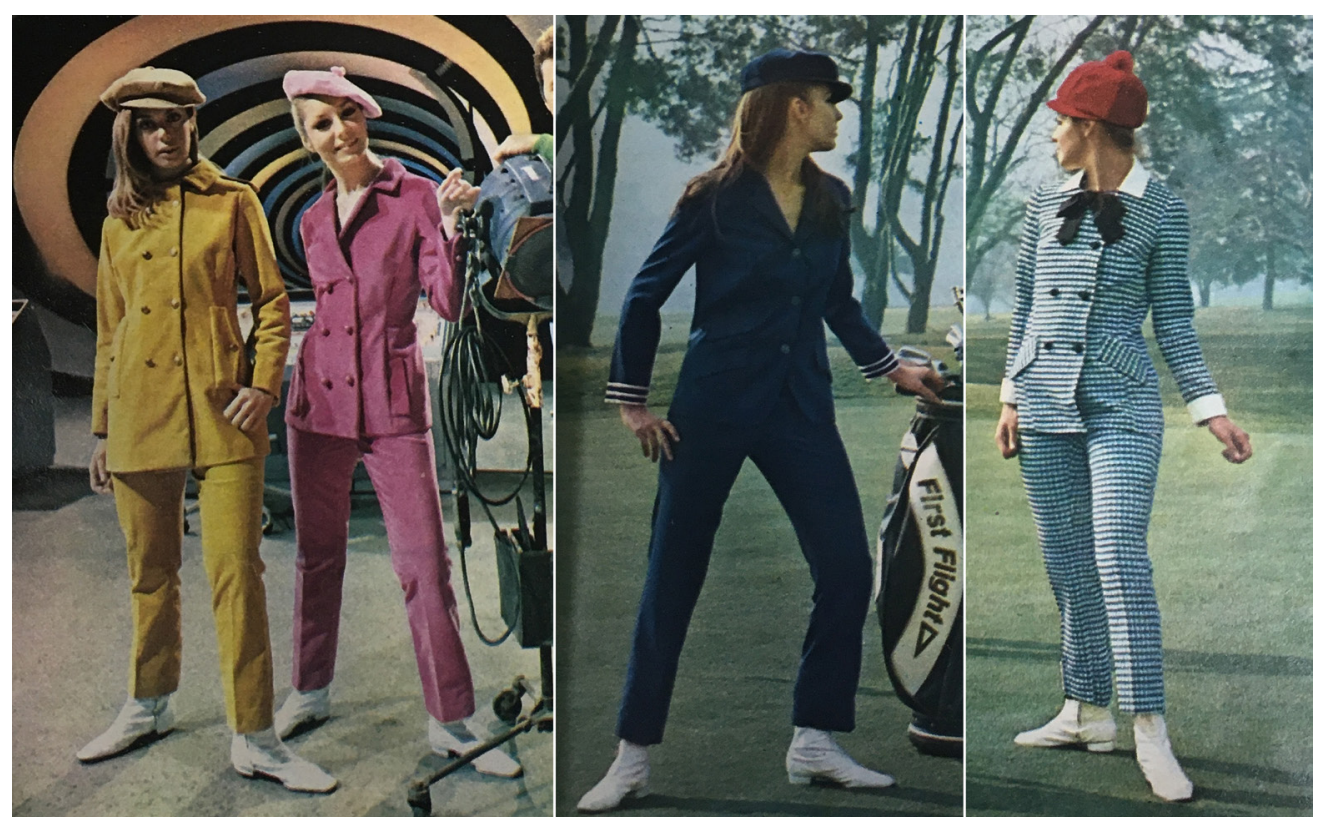

Figura 13 - Mila e Betina usam botinhas brancas à moda de Courrèges. Fonte: Claudia. Acervo Biblioteca Nacional - Rio de Janeiro.

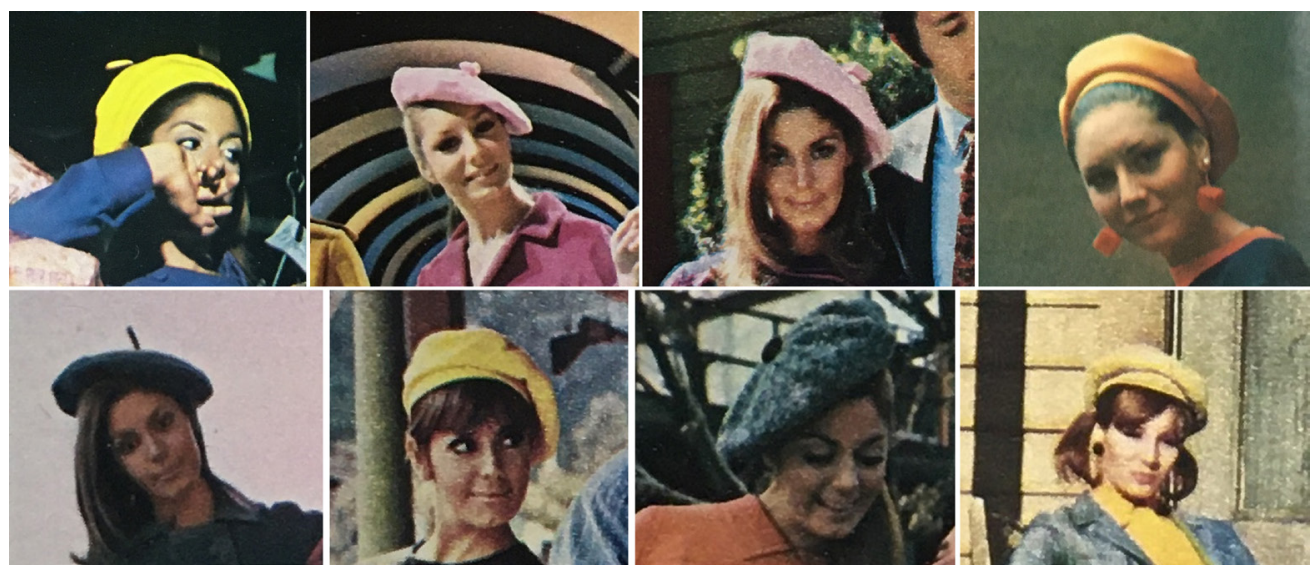

Figura 14 - Bloco que demonstra o uso de boinas no editorial. Fonte: Claudia. Acervo Biblioteca Nacional - Rio de Janeiro. 


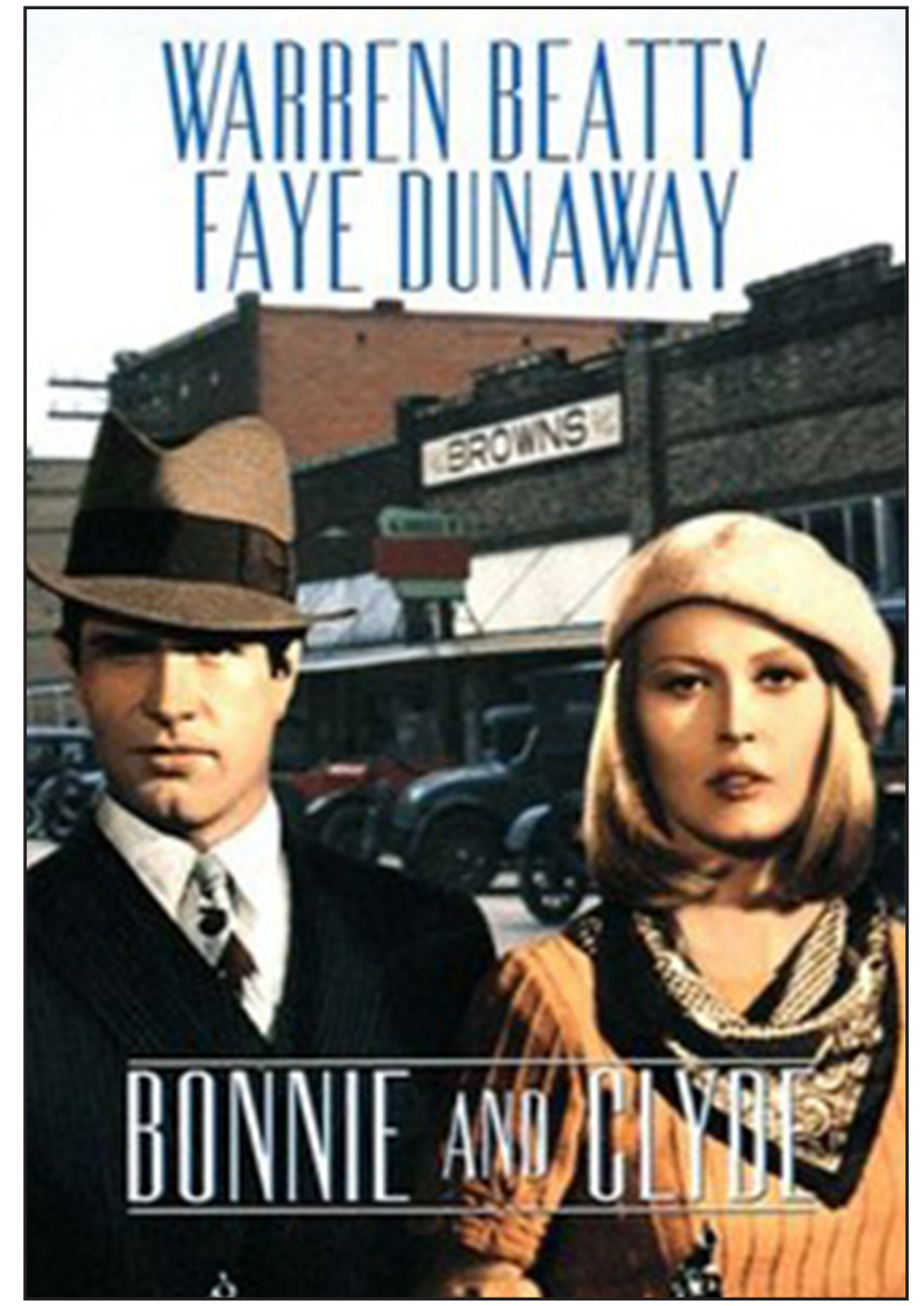

Figura 15 - Cartaz do filme Bonnie e Clyde: uma rajada de balas, no qual a atriz Faye Dunaway aparece trajando uma boina. Fonte: Adoro Cinema. Disponivel em: <https:// bit.ly/318bFTs>

Outro acessório que permeia o editorial é a boina (Figura 14). A peça se popularizou nos anos 1960 com o lançamento de Bonnie e Clyde: uma rajada de bala (Arthur Penn, 1967), filme que alcançou sucesso na história do cinema ao narrar as aventuras de um casal de bandidos dos anos 1930 (Figura 15). O longa foi considerado um dos marcos dos anos 1960, pois quebrou tabus cinematográficos ao "glorificar" assassinos e retratar a violência nas telas, e acabou por se tornar popular entre os jovens por ser considerado um símbolo da contracultura da época. Porém, o filme foi lançado em setembro de 1967, e o editorial foi publicado em abril do mesmo ano, de modo que a presença das boinas não pode ser explicada como influência do filme na moda do momento. De acordo com Maíra Zimmermann de Andrade, a peça já aparecia como tendência na moda britânica de 1940, 
113. Andrade (2016).

114. Ibid.

115. Gellacic (2018).

116. Gellacic (2018, p. 136).

117. Ibid. devido à influência do estilo francês. ${ }^{113}$ Assim, o acessório já estava sendo usado entre as mais "antenadas" e, talvez, tenha se popularizado posteriormente com o lançamento do longa, o que pode nos sugerir que a revista e o anunciante já traziam em suas produções elementos vanguardistas da moda.

As cores também marcam a moda da juventude deste período. $\bigcirc$ advento dos fios sintéticos possibilitou a confecção de roupas com estampas e cores mais fortes e nítidas, abrindo possibilidades de produtos mais baratos e em larga escala para o público jovem que se consolidava. ${ }^{114}$ No editorial podemos ver como peças e acessórios coloridos predominam nos looks usados pelas modelos e, além disso, aparecem também no design das páginas, através de fontes e elementos gráficos, indicando certa psicodelia visual.

Porém, apesar das cores atrativas e das principais tendências do momento, não podemos afirmar que Claudia e Rhodia apresentem roupas destinadas ao público jovem, mas, sim, à jovem senhora, à "mulher-ornamento", uma adulta atenta às novidades da moda, mas sem perder a elegância, sendo, assim, dotada de uma noção de gosto distinto, que se encontra entre a novidade e a tradição.

Esta mistura entre tradição e modernidade nas poses pode ser explicada pela divisão que Gisele Bischoff Gellacic faz da liberalização dos costumes. ${ }^{115} \mathrm{~A}$ autora afirma que há três fases nesse processo: a primeira se refere ao período entre os anos 1961 e 1967; a segunda a partir de 1967 até meados de 1970; e a terceira de 1970 a 1985. Ao considerarmos que este editorial é datado de 1967, podemos compreendê-lo como uma fase de transição entre as duas primeiras fases, porém, as imagens nos mostram como ele está mais alinhado com as características da fase intermediária. Conforme a autora, o primeiro momento traz um início de liberação, mas ainda muito marcado pelo imaginário da feminilidade voltada para o lar e para a vida doméstica, enquanto o segundo apresenta novas propostas de funções sociais às leitoras. Além disso, enfatiza que

Liberar o corpo, segundo a imprensa feminina [...] nunca significou ter a total liberdade de fazer o que quisesse sexualmente e sensualmente, ou ainda, não significava ter qualquer tipo de corpo. Pelo contrário, as revistas demonstravam, através de sua conversa amiga, as fórmulas, as posições, os gestos e as maneiras de ser liberada. ${ }^{116}$

De acordo com Gisele Bischoff Gellacic, as revistas eram um veículo de legitimação dos papéis sociais para as leitoras, agindo, assim, como um manual das performances consideradas femininas. ${ }^{117}$ Deste modo, podemos compreender os editoriais da Rodhia publicados pela Claudia como uma forma de ensinar a 
mulher das camadas médias em ascensão a se vestir e se comportar em meios às transformações por que a sociedade passava nesse período.

Assim, partindo do pressuposto de que as revistas femininas dialogam com

o tempo no qual estão inseridas, é possível acompanhar através de suas páginas alterações em termos de valores e comportamentos socialmente aceitos. ${ }^{118}$ Assim, "não há certezas, fórmulas, ou uma visão única de como deveriam ser as novas posturas femininas frente à liberação corporal e sexual. [... ] A liberação não estava pronta, assim como as opiniões veiculadas em Claudia". 119

Deste modo, Claudia, enquanto revista feminina contextualizada em um período de mudanças de costumes, transmite no editorial em questão essa tensão entre o tradicional e o moderno, a "mulher-ornamento" e a "mulher dinâmica", a passividade e a atividade que caracterizam a década de 1960.

\section{CONSIDERAÇÕES FINAIS}

As transformações econômicas, sociais, políticas e econômicas ocorridas no Brasil a partir dos anos 1950, advindas da crescente industrialização e urbanização, levaram à gestação de uma nova classe média voltada para os ideais da modernidade e consumo. Somando-se a isso, a partir dos anos 1960, o país também testemunhou uma mudança nos costumes que impactaria o papel social da mulher e suas representações.

A revista Claudia se desenvolveu neste contexto, imbricada com aspectos da modernização da sociedade brasileira e com a constituição da sociedade de consumo, criando a concepção da "mulher moderna" como modelo de feminilidade. Através de suas páginas, é possível compreender as transformações vividas pelo país neste momento, uma vez que a imprensa feminina funciona como um reflexo da sociedade e, assim, reforça, cria ou difunde representações e estereótipos de feminilidade que ajudam a moldar a identidade da leitora. ${ }^{120}$

Assim, ao analisarmos as fotografias do editorial "À moda de Hollywood" publicado pela revista em 1967 em parceria com a empresa Rhodia, podemos ver não só essas transformações estampadas, mas também como os valores da época estão presentes em meio a fotos que a princípio parecem apenas vender um produto. As poses, cenários, roupas e gestos nos mostram que, no editorial em questão, preceitos tradicionais e modernos convivem e se misturam. Diante de roupas simbólicas dos novos tempos, podemos ver como ainda resistem posturas 
femininas submissas com poses contidas e estáticas, em detrimento do dinamismo masculino dos automóveis. Estas considerações nos mostram como as transformações de costumes não ocorrem de forma abrupta, mas sim fluida.

Além disso, o editorial nos mostra como a revista assume o papel de guia para sua leitora. Se novos tempos trazem roupas e modas inéditas, é preciso que a "mulher moderna" da classe média em ascensão esteja preparada e saiba como, onde e quando usar essas peças, através de um vocabulário de gestos que se repetem em desacordo com as roupas ditas modernas. Assim, Claudia ensina, por meio do olhar, como se portar ao usar uma minissaia ou uma calça comprida. Ela também instrui que, embora haja uma flexibilização dos costumes, isso não se dá de qualquer forma: há maneiras corretas e equivocadas de se portar diante de um homem e da sociedade. Deste modo, ainda que haja maior liberalização nos costumes, é importante ressaltar que isto acaba por significar novas amarras, uma vez que, diante de moldes inéditos, há a necessidade um novo repertório de comportamentos, gestos e posturas a serem aprendidos e perpetuados.

O editorial em questão também nos chama a atenção para a estratégia da Rhodia de difundir através das fotografias a versatilidade de seu fio sintético. Pois, além de indicar a variedade de peças que podem ser feitas a partir do material, também transmite a sua flexibilidade de uso, uma vez que pode ser utilizado para passear de carro esporte, jogar golfe, remar, dançar no telhado ou dar uma volta pelo "velho oeste" acompanhada pelos astros do momento. 


\section{REFERÊNCIAS}

LIVROS, ARTIGOS E TESES

ADAMATTI, Margarida Maria. A crítica cinematográfica e o star system nas revistas de fãs: a Cena Muda e Cinelândia (1952 - 1955). 2008. Dissertação (Mestrado em Estudos do Meio e da Produção Mediática) - Escola de Comunicações e Artes, Universidade de São Paulo, São Paulo, 2008.

ANDRADE, Maíra Zimmermann de. Rebeldia pronta para o consumo: a construção da cultura juvenil no Brasil dos anos 1950-60. 2016. Tese (Doutorado em Política, Memória e Cidade) Instituto de Filosofia e Ciências Humanas, Universidade Estadual de Campinas, Campinas, 2016.

BARTHES, Roland. A mensagem fotográfica. In: BARTHES, Roland. O óbvio e o obtuso. Rio de Janeiro: Nova Fronteira, 1990. p. 11-43.

BERGER, John. Modos de ver. Lisboa: Edições 70, 1972.

BONADIO, Maria Claudia. Moda e publicidade no Brasil nos anos 1960. São Paulo: nVersos, 2014.

BUITONI, Dulcília Schroeder. A mulher de papel: a representação da mulher pela imprensa feminina brasileira. São Paulo: Summus, 2009.

CICCO, Cláudio de. Hollywood na cultura brasileira: o cinema americano na mudança da cultura brasileira na década de 40. São Paulo: Convívio, 1979.

COSTA, Maria Paula. Entre sonhos e consumo: as representações femininas na Revista Claudia (1961-1985). 2009. Tese (Doutorado em História) - Faculdade de Ciências e Letras, Universidade Estadual Paulista, Assis, 2009.

DUBY, Georges; PERROT, Michelle (orgs.). História das mulheres no Ocidente: o século XX. Porto: Afrontamento, 2007.

HOBSBAWM, Eric. Era dos extremos: o breve século XX (1914-1991). São Paulo: Companhia das Letras, 1995.

FIGUEIREDO, Anna Cristina Camargo Moraes. "Liberdade é uma calça velha, azul e desbotada": publicidade, cultura de consumo e comportamento político no Brasil (1954-1964). São Paulo: Hucitec, 1998.

GELLACIC, Gisele Bischoff. Despindo corpos: uma história da liberação sexual feminina no Brasil 1961-1985. São Paulo: Alameda, 2018. 
GOFFMAN, Erving. Gender advertisement. Nova York: Harper \& Row, 1979.

LIPOVETSKY, Gilles. O império do efêmero: a moda e seu destino nas sociedades modernas. São Paulo: Companhia das Letras, 2009.

LUCA, Tânia Regina. Mulher em revista. In: PINSKY, Carla Bassanezi; PEDRO, Joana Maria (orgs.). Nova história das mulheres no Brasil. São Paulo: Contexto, 2012. p. 447-468.

MAUAD, Ana Maria. Na mira do olhar: um exercício de análise da fotografia nas revistas ilustradas cariocas, na primeira metade do século XX. Anais do Museu Paulista, São Paulo, v. 13, n. 1, p. 133-174, 2005. Disponível em: <https://bit.ly/3sj7QXG>. Acesso em: 29 dez. 2018.

MELLO, João Manuel Cardoso de; NOVAIS, Fernando A. Capitalismo tardio e sociabilidade moderna. In: SCHWARCZ, Lilia Mortiz. História da vida privada no Brasil: contrastes da intimidade contemporânea. São Paulo: Companhia das Letras, 1998.

MENDES, Valerie; HAYE, Amy de la. A moda do século XX. São Paulo: Martins Fontes, 2009.

MIRA, Maria Celeste. O leitor e a banca de revistas: a segmentação da cultura no século XX. São Paulo: Olho d'Água: Fapesp, 2008.

MONJABOSCO, Ângelo. Lew Parrella: cidadão americano, fotógrafo brasileiro. Revista ZUM, São Paulo, jul. 2015. Disponível em: <https://bit.ly/2QwL6oY>. Acesso em: 17 jul. 2020.

ORTIZ, Renato. A moderna tradição brasileira: cultura brasileira e indústria cultural. São Paulo: Brasiliense, 1988.

PRADO, André Luis do; BRAGA, João. História da moda no Brasil: das influências às autorreferências. Barueri: Disal, 2019.

PINSKY, Carla Bassanezi. Mulheres dos anos dourados. São Paulo: Contexto, 2014.

PINSKY, Carla Bassanezi. A era dos modelos flexíveis. In: PINSKY, Carla Bassanezi; PEDRO, Joana Maria (orgs.). Nova história das mulheres no Brasil. São Paulo: Contexto, 2012. p. 513-544.

RAINHO, Maria do Carmo. Moda e revolução nos anos 1960. Rio de Janeiro: Contra Capa, 2014.

SVENDSEN, Lars. Moda: uma filosofia. Rio de Janeiro, Zahar, 2010.

VEBLLEN, Thortein. A teoria da classe ociosa. São Paulo: Abril Cultural, 1983. 


\section{ENTREVISTAS}

GATTI, Mario; AURÉLIO, Antônio. Entrevista concedida a Maria Claudia Bonadio. São Paulo, 27 fev. 2002.

FILMES

Diana Vreeland: the eye has to travel. Direção: Lisa Immordino Vreeland, Frédéric Tcheng, BentJorgen Perlmutt. Roteiro: Lisa Immordino Vreeland. [S. l.]: Lisa Immordino Vreeland, 2011. 1 DVD (76 min), son., col.

Artigo apresentado em: 18/09/2020. Aprovado em: 15/02/2021.

\section{(cc) BY}

